Universidade de Brasília

Instituto de Relações Internacionais

Programa de Pós-Graduação em Relações Internacionais

\title{
A ATUAÇÃO DAS EMPRESAS BRASILEIRAS NA ÁFRICA NO GOVERNO LULA
}

Júlia Covre Vilas-Bôas

Monografia apresentada como requisito parcial para a obtenção do título de especialista em Relações Internacionais pela Universidade de Brasília, sob a orientação do Prof. Dr. Pio Penna Filho. 


\section{RESUMO}

Esta monografia trata da atuação das empresas brasileiras na África durante o governo Lula, período em que houve um incremento dessa presença, motivado não apenas por mudanças nas condições de estabilidade do continente africano, mas também por investimentos diplomáticos do Brasil em direção aos países da África e por condições econômicas internas também favoráveis, que possibilitaram o crescimento econômico e o robustecimento das empresas brasileiras. Do lado da África, a nova inserção do continente se subdivide no espírito autonomista da NEPAD e em uma "nova partilha da África” pelos países interessados em investir no continente. Do lado do Brasil, a política externa do governo Lula busca reverter o afastamento que vinha se desenhando nos anos 1990, com o incremento não apenas do incentivo à atuação das empresas brasileiras, mas também da cooperação, do comércio e dos encontros de alto nível. A atuação das empresas brasileiras na África do Sul, Angola, Líbia e Moçambique são apresentados nesse trabalho para ilustrar esses investimentos. 


\begin{abstract}
This monograph treats about the performance of Brazilian companies in Africa during Lula's government, time in which there was an increase in its presence motivated by, not only changes in the conditions of stability in Africa, but also by Brazilian diplomatic investments through African countries and by also favorable internal Brazilian economic conditions, which enabled economic growth and strengthen Brazilian companies. On the Africa side, the new international integration divides in the NEPAD's autonomist mood and a "new scramble for Africa" by the countries interested in investing in the continent. On the Brazil side, Lula government foreign policy pursuit revert the distance settled during the 1990's, by improving not only incentives to the Brazilian companies but also bilateral cooperation, commerce and high level meetings. The performance of the Brazilian companies in South Africa, Angola, Libya and Mozambique are presented in this work to illustrate these investments.
\end{abstract}




\section{SUMÁRIO}

Lista de Acrônimos....................................................................................... 5

Introdução......................................................... 6

1. A Nova Inserção da África.......................................... 9

1.1. NEPAD - New Partnership for Africa Development..............................13

1.2. A Redescoberta da África..........................................16

2. A Política Externa Brasileira para a África sob o Governo Lula...............22

2.2. As Escolhas Seletivas dos anos 1990 e a preparação para os dias atuais..23

2.3.A Política Externa do Governo Lula para a África....................................26

3. Os Investimentos Brasileiros na África....................................................34

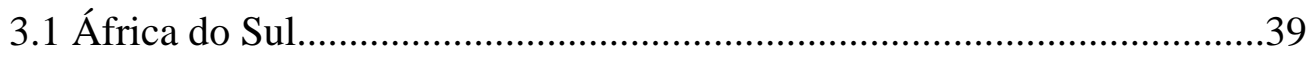

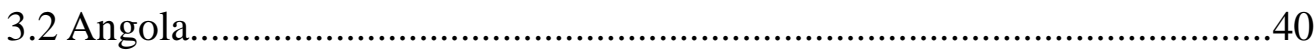

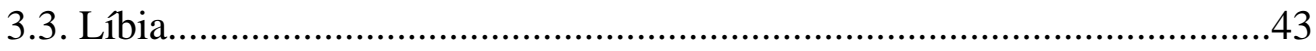

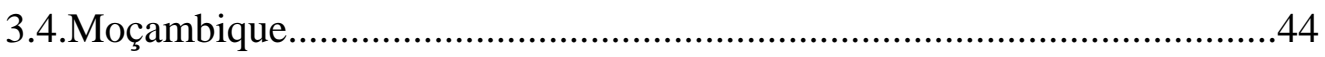

3.5. Franquias de Marcas Brasileiras...........................................................46

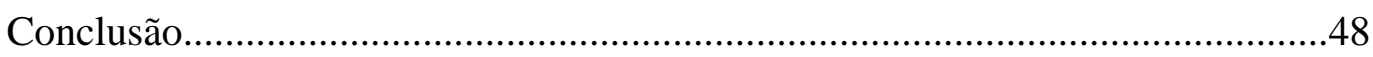

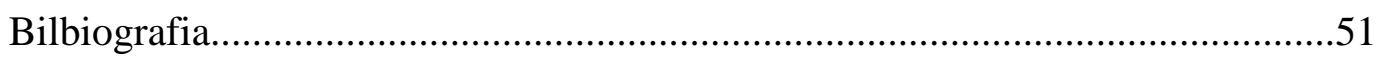




\section{LISTA DE ACRÔNIMOS}

APEX-Brasil - Agência Brasileira de Promoção de Exportações e Investimentos ASACOF - Africa-South America Cooperative Forum

BRIC - Brasil, Rússia, Índia e China

CIA - Central Intelligence Agency

CPLP - Comunidade dos Países de Língua Portuguesa

C.S. - Conselho de Segurança das Nações Unidas

Embrapa - Empresa Brasileira de Pesquisa Agropecuária

FAO - Food and agriculture Organization of the United Nations

Fiocruz - Fundação Oswaldo Cruz

FILDA - Feira Internacional de Angola

IBAS - Índia, Brasil e África do Sul

MAP - Millenium Partnership for the African Recovey Programme

MPLA - Movimento Popular para a Libertação de Angola

NEPAD - New Partnership for African Development

ODA - Official Development Assistance

OUA - Organização da Unidade Africana

PALOP - Países Africanos de Língua Portuguesa

SACU - Southern Africa Customs Union

SENAI - Serviço Nacional de Aprendizagem Industrial

UA - União Africana

Unasul - União das Nações Sul-Americanas

Unita - União Nacional para a Independência Total de Angola

ZOPACAS - Zona de Paz e Cooperação do Atlântico Sul.

NOC - National Oil Corporation

LBCD - Libyan-Brazilian Construction \& Development

UDHC - Urban Development Holding Company 


\section{INTRODUÇÃO}

A África está presente nas relações internacionais do Brasil mesmo antes da estruturação deste como Estado, compondo o dinâmico comércio que funcionava à margem das regras de exclusivo do império colonial português. Nesse período, os contatos eram intensos tanto no nível comercial como de proximidade entre as elites, em especial aquela dedicada ao tráfico de escravos. Nesse sentido, Costa e Silva afirma que

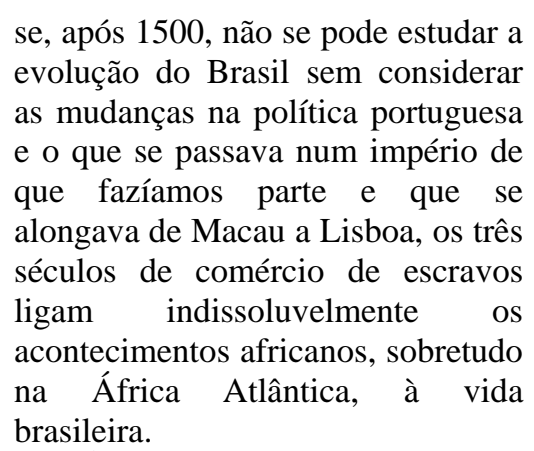

Depois de um longo período de esquecimento da África por parte do Brasil, após o fim da escravidão e do tráfico negreiro, Costa e Silva afirma que o esforço por repensar o diálogo brasileiro com o continente africano, sobretudo a ação políticodiplomático, data só das vésperas das independências africanas. Nesse interregno, os países da África mantiveram-se sob o sistema colonial, enquanto o Brasil estruturava-se como Estado independente.

Ao longo da segunda metade do século XX a aproximação foi progressiva, indo desde o discurso que não encontrava sustentação nas ações práticas até uma ênfase mais pragmática, na década de 1970, intercalada de alguns períodos de distanciamento. Enquanto isso, no continente africano, os processos de independência se desenrolavam, uns mais brandos, outros com extrema violência.

No século XXI, porém, em ambos os lados do Atlântico a disponibilidade de condições internas junta-se à vontade política e as relações ganham novo ímpeto. No momento atual, ao invés de incremento apenas de fluxos de um comércio que nem legítimo era ${ }^{1}$, a sofisticação das relações internacionais e a complexidade dos Estados e das economias internas ${ }^{2}$ convertem essa nova aproximação em

\footnotetext{
${ }^{1}$ Referência ao comércio triangular do período colonial, que ocorria à margem e em contradição com o exclusivo colonial.

${ }^{2}$ Muito mais da parte do Brasil do que da parte dos países africanos.
} 
investimentos diretos, visitas de alto nível, coordenação de posições no âmbito das relações Sul-Sul, além do incremento do comércio, mas agora com uma pauta mais sofisticada.

Essa monografia tem o objetivo de analisar uma das vertentes dessa nova aproximação entre Brasil e África, a da atuação das empresas brasileiras no continente. O que se pretende é mapear esses investimentos, identificando em quais países eles se localizam, em quais ramos da atividade econômica eles se inserem e que tipos de empresa se predispõem a investir no continente. Para isso, foi feito um levantamento bibliográfico em livros, mas, principalmente, jornais, periódicos, sites oficiais de empresas e relatórios e pesquisas de instituições voltadas para a área de investimentos externos, tendo em vista a atualidade do tema e a exígua disponibilidade de obras que analisem os investimentos brasileiros na África.

Dessa forma, em um primeiro momento será estudada a nova inserção internacional da África no século XXI, após a superação da perda de importância estratégica, ocorrida nos anos 1990. Um panorama de como essa inserção se deu desde as independências, em meio à Guerra Fria, até os anos 2000 inicia o primeiro capítulo, que é seguido por uma análise da NEPAD, que corresponde ao motor interno do Renascimento Africano, e pela "nova partilha da África”, a qual corresponde ao motor externo desse renascimento. Essa sessão analisará a contribuição conjuntural por parte da África para que os investimentos brasileiros no continente tenham crescido na última década.

No segundo capítulo, será analisada a política externa do governo Lula, consistindo a outra vertente da contribuição conjuntural para o incremento das relações bilaterais. O capítulo se inicia com a apresentação das principais iniciativas de aproximação com a África ao longo do século XX, quais sejam a Política Externa Independente (PEI) e o Pragmatismo Responsável e Ecumênico. Em seguida, na sessão 2.1. analisa-se o afastamento do Brasil em relação à África na década de 1990. Enfim, no item 2.2 a política externa do governo Lula para a África é analisada, com destaque para a análise de em que ela se difere de outras iniciativas de aproximação mais intensa.

No terceiro e último capítulos, será analisada a etapa atual no processo de internacionalização da economia brasileira - que corresponde ao da 
internacionalização de empresas nacionais -, as iniciativas governamentais para fomentar o fluxo de investimentos diretos brasileiros para a África e a análise do perfil e da localização desses investimentos. Ao longo desse capítulo serão estudados os países onde a presença de empresas brasileiras é mais significativa, quais sejam África do Sul, Angola, Líbia e Moçambique, respectivamente. Essa sequencia, contudo, não representa uma hierarquia de importância, mas apenas uma enumeração em ordem alfabética. 


\section{A NOVA INSERÇÃO INTERNACIONAL DA ÁFRICA:}

A inserção internacional da África independente, assim como o processo de independência de muitos de seus países, se deu em meio à Guerra Fria. Essa inserção deu-se tanto por meio de uma tentativa de autonomia, com o Movimento dos NãoAlinhados e a luta por uma Nova Ordem Econômica Internacional (NOEI), quanto com seus conflitos internos sendo instrumentalizados pelas disputas entre as duas potências. Nesse sentido, no período da Détente ${ }^{3}$, os conflitos entre Estados Unidos e União Soviética foram, em grande medida, transferidos para os países periféricos, em especial os da África, atribuindo caráter estratégico à região.

O fim da Guerra Fria, assim, impôs uma nova condição às relações internacionais da África. A perda da importância estratégica que estes países tinham nas disputas bipolares fez com que, na década de 1990, o continente fosse relegado ao esquecimento, tendo, a partir de então, que lidar com os conflitos inacabados, remanescentes das disputas entre as antigas potências, que ainda foram agravados pela marginalização estratégica, pela perda de capacidade de barganha, pela perda de importância econômica, pelas consequências da década perdida e pela subsistência de paradigmas coloniais.

Em um primeiro momento do pós-Guerra Fria, sobreveio em partes da África ventos democratizantes, associados à nova ordem mundial. Exemplos disso são o fim do Apartheid na África do Sul, em 1991, e a libertação de Nelson Mandela, no ano anterior, a retirada dos cubanos de Angola, em 1989, e assinatura de acordo de paz, em 1991, a queda de regimes marxistas, como o da Etiópia, e a realização de eleições democráticas na Namíbia, em 1991, sob os auspícios da ONU.

Muitas dessas iniciativas, porém, não se sustentaram, como no caso de Angola, em que a guerra civil só foi encerrada definitivamente em 2002, após a morte de Jonas Savimbi, líder da Unita, grupo rival ao governo do MPLA, instalado em Luanda. De outra forma, muitas democracias que foram impostas de fora para dentro, após a queda do Muro de Berlim, no que Samuel Huntington chamou de “Terceira Onda”, estão retrocedendo, com a volta ao poder de antigos líderes de

\footnotetext{
${ }^{3}$ Observar a divisão dos períodos da Guerra Fria feitos por Saraiva, em História das Relações Internacionais Contemporâneas.
} 
regimes autoritários. Além disso, outras tragédias marcaram a África na década de 1990, como o massacre de Ruanda e a fome na Somália.

Portanto, segundo Paulo Fagundes Vizentini, o contexto do continente africano nos no pós-Guerra Fria foi de "marginalização da África no sistema internacional, [de] desestrategização e tribalização dos conflitos e da política regional”. (VIZENTINI, 2007)

Os conflitos intra e interestatais, além de gerar milhares de mortos e refugiados, destruir a infraestrutura dos países e desarticular a agricultura e os setores produtivos das economias africanas, deslocavam os orçamentos da área de educação e saúde para a compra de armas que alimentavam essas guerras. Ademais, o alastramento de epidemias de cólera, ebola e, em especial, a de Aids ${ }^{4}$, e o crescimento do tráfico de armas, drogas e pedras preciosas, com o empoderamento de suas redes criminosas e máfias, agravava ainda mais a situação do continente.

Se no período da Guerra Fria, a existência dos conflitos já levava à desorganização e pauperização do continente, na década de 1990 essa situação era agravada, na medida em que os países, além de não acabar com os conflitos, perdiam o apoio financeiro e estratégico das potências, que contribuíam para manter a coesão social. Os conflitos, por sinal, tornaram-se endêmicos, foram agravados ou, em alguns casos, surgiram novos conflitos, resultantes das disputas pelo controle dos Estados. Essa situação fez com que avultasse o “afropessimismo” nas análises a respeito do continente. Nesse sentido, o Banco Mundial chegou a estimar que, ao ritmo dos anos 1990, seriam necessários quarenta anos para que a África negra recuperasse o nível dos anos 1970. (SARAIVA, 2008)

Diante da “tragédia Subsaariana”, multiplicou-se o número de operações de paz das Nações Unidas na África e as grandes potências, assim como a ONU, engajaram-se em políticas de ajuda humanitária à África, as quais delimitaram a participação do continente nas relações internacionais naquela década. Propostas assistencialistas, na maioria das vezes condicionadas a reformas liberais, que canalizavam recursos dos países ricos para a região, foram ineficazes em combater os males africanos e, diante do seu fracasso, foram sendo abandonadas na virada do

\footnotetext{
${ }^{4}$ De acordo com a UNAIDS, 34\% do total de pessoas infectadas pelo vírus da Aids no mundo estão localizadas em 10 países da África Austral. A mesma instituição, porém, apresenta números otimistas: entre 2001 e 2009, a incidência de HIV em 22 países da África Subsaariana caiu 25\%.
} 
milênio.

No início do século XXI, passado o hiato do pós-Guerra Fria, a África, nas palavras de Vizentini, dá uma "nova arrancada” e assume um novo patamar de inserção internacional. De acordo com José Flavio Sombra Saraiva, são três os conceitos centrais que alimentam essa transformação: avanço gradual dos processos de democratização e contenção dos conflitos armados - reduzidos de 13 para 5 -; crescimento econômico alicerçado em responsabilidade fiscal e preocupação social; e elevação da autoconfiança das elites por meio de novas formas de renascimento cultural e político.

Enquanto no aspecto político destaca-se o protagonismo de África do Sul, Líbia, Nigéria, Argélia e Senegal na transformação da OUA em UA e no lançamento da NEPAD $^{5}$, no plano econômico, a pujança industrial sul-africana e os vultosos recursos petrolíferos da Argélia, Nigéria e Líbia somaram-se ao forte incremento dos investimentos e do comércio promovidos pela China, em especial, mas também, Índia, Brasil e Países Árabes. Além disso, a África, como tradicional exportadora de commodities e produtos agrícolas, vem se beneficiando da valorização de algumas commodities e da demanda por recursos estratégicos que o crescimento chinês impõe e que a África tem em abundância.

A África do Sul pós-Apartheid tem também atuado na diplomacia mundial com vistas a reformar as instituições internacionais, no intuito de essa governança reformada proporcionar um mundo mais multipolar e onde os países africanos tenham mais voz. Esse país também tem promovido ativamente o multilateralismo no continente africano, como, por exemplo, com a criação da Comunidade para o Desenvolvimento da África Austral (SADC) e o crescimento do número de conferências multilaterais sediadas em países africanos ${ }^{6}$.

A reafirmação da autonomia política da África e a recuperação seu poder de barganha puderam ser observados em 2003, quando a União Africana posicionou-se frontalmente contrária a qualquer ataque ao Iraque, sem que os inspetores da ONU tivessem concluído seus trabalhos e o Conselho de Segurança (C.S.) tivesse aprovado

\footnotetext{
${ }^{5}$ A NEPAD - New Partnership for African Development sera vista no item seguinte deste capítulo.

${ }^{6}$ São exemplos, a III Conferência da ONU contra o Racismo, a Discriminação Racial, a Xenofobia e a Intolerância Correlata, realizada na África do Sul em 2001, e a Cúpula da Terra, ou Rio + 10, sobe meio ambiente e desenvolvimento sustentável, realizada no ano seguinte no mesmo país.
} 
a invasão. Mais ainda, pelo fato de os membros africanos do C.S. terem sido cotejados pelos EUA e a França e terem mantido suas posições.

Tudo isso resultou em uma forte aceleração no crescimento econômico e uma atitude mais assertiva nas relações internacionais dos países africanos. Esse é o Renascimento Africano.

Ao longo da primeira década do século XXI, a África teve crescimento médio de $5 \%$ a $6 \%$, suas taxas médias de inflação foram contidas em $6 \%$ e as exportações em 2006 e 2007 ficaram em 43\% e 45\% do PIB, enquanto os investimentos externos correspondem, na média, a 19,4\% do PIB - percentual muito próximo ao do Brasil, embora considerado baixo para a sustentabilidade econômica (SARAIVA, 2008: 88).

Da perspectiva acadêmica, o renascimento corresponde a uma tendência dos africanos de passar em revista os descaminhos de várias experiências de importação de modelos. A ideia de aproveitar oportunidades inéditas permeia o novo discurso interno da inteligência africana.

A despeito das mudanças, ainda existem algumas preocupações que pairam sobre o continente, como as políticas de metas de redução da pobreza, que em muitos países ainda são preocupantes, a possibilidade de um novo ciclo de endividamento, gerado, principalmente, pela política chinesa na África, a pouca diversificação da economia africana e a persistência de corrupção.

Além disso, a crise financeira internacional lançou novos desafios. A economia africana não foi tão afetada quanto a dos países desenvolvidos, mas houve uma redução de investimentos chineses, logo compensados por avanço de capitais do Golfo Persico. Em suma, o continente continua vivendo um ciclo de crescimento, mas é justamente nesse ponto que reside o desafio para o futuro, na medida em que se questiona como o crescimento será mantido em contexto de menos capital internacional disponível para investimentos.

Mesmo assim, a África tem apresentado números e iniciativas tanto positivos como inovadores, que levam o continente a ser visto como a nova fronteira do capitalismo.

O renascimento africano e sua nova inserção internacional estão calcados em dois pilares, um interno - A NEPAD -, responsável pelo espírito de auto-gestão do continente, sem interferências externas e promovendo seu próprio desenvolvimento, 
e um externo, que é a redescoberta do continente pelos investidores externos e o processo que vem sendo chamado de “nova partilha da África”.

\subsection{NEPAD - New Partnership for Africa Development:}

A NEPAD é um programa da União Africana, adotado em 2001, com propostas autóctones e levadas a cabo por africanos. Esse documento está associado ao "Renascimento Africano” por representar uma iniciativa de retomada de confiança e reconstrução da identidade do continente. Nesse sentido, as lideranças africanas declaram estar tomando as rédeas dos seus próprios destinos, recusar-se a aceitar lideranças econômicas e políticas desqualificadas e ser condicionados pelas circunstâncias.

De acordo com José Flávio Sombra Saraiva (2002), em certa medida, o NEPAD não é exatamente algo inédito na política africana, na medida em que há nele uma forte contribuição de projetos anteriores, como o African Renaissence, do fim dos anos 1990, do Plano Ômega, do Senegal, e o Millennium Partnership for the African Recovery Programme (MAP), da África do Sul. Nigéria, África do Sul e Senegal, dessa forma, tornaram-se protagonistas do Plano NEPAD.

Apesar de ter raízes em outros projetos prévios, a NEPAD constitui uma reação construtiva das lideranças africanas em tempos difíceis e Saraiva considera que há certa originalidade no documento.

Parte da retomada da autoestima e reconstrução da identidade africana, segundo o documento, depende da consciência do povo africano em relação à sua contribuição para o mundo e da valorização da mesma, seja por a África ser o berço da humanidade, seja por possuir recursos minerais, ecológicos e culturais. A autoconfiança que emerge, porém, resguarda que esses recursos sejam utilizados para gerar riquezas e bem-estar para os próprios africanos.

O objetivo do NEPAD é erradicar a pobreza e colocar os países africanos, tanto individualmente quanto coletivamente, no caminho do crescimento e desenvolvimento sustentáveis e acabar com a marginalização da África no processo de globalização.

A agenda proposta pelo NEPAD visa à renovação do continente, baseada em 
prioridades nacionais e regionais, quais sejam: prevenção, administração e resolução de conflitos; democracia e direitos humanos, por meio do desenvolvimento de padrões claros de verificação, transparência e governança participativa; estabilidade macroeconômica; estabelecer um enquadramento legal e regulatório transparente nos mercados financeiros e auditar o setor público e privado; promoção da educação, treinamento técnico e saúde, com prioridade para o problema da Aids, malária e outras doenças contagiosas; promoção do papel da mulher; promover o desenvolvimento da infraestrutura, da agricultura e a diversificação entre a agroindústria e as manufaturas; e fortalecer o Estado para ser capaz de criar e impor regras legais e manter a ordem.

Um dos pilares da NEPAD é a tentativa de reverter a situação de miséria e exclusão em que o continente esteve inserido nos anos 1990 por meio da mudança no nível de relações internacionais que a sustentaram. Trata-se de um apelo por um novo relacionamento de parceria entre a África e a comunidade internacional, em especial os países desenvolvidos, visando superar o passado de relações desiguais. Paradoxalmente, o documento confirma que várias parcerias entre a África e os países desenvolvidos e as organizações internacionais serão mantidas.

Além de ter metas similares aos Objetivos do Milênio propostos pelas Nações Unidas, a NEPAD tem metas ambiciosas, como atingir e manter um PIB médio dos países em 7\% a.a. nos quinze anos seguintes à elaboração do documento. Dentre as estratégias para atingir esses objetivos está a diversificação das atividades produtivas, o estimulo à competitividade e o incremento das exportações.

Tudo isso depende da construção de uma economia forte e competitiva, que, em contexto de globalização, torna-se condição necessária para retirar a África da marginalização e para que ela possa efetivamente participar da economia global e da política internacional. Os líderes da NEPAD identificam que se os enormes recursos naturais e humanos do continente forem utilizados de forma apropriada será possível alcançar desenvolvimento equitativo e sustentável.

A ideia do projeto é preencher lacunas em setores estratégicos, quais sejam: infraestrutura, tecnologia da informação e comunicação digital, energia, transportes, redução da pobreza, educação, redução da fuga de cérebros, saúde, agricultura, meio ambiente, cultura e ciência e tecnologia. O papel do Estado é destacado no 
crescimento e no desenvolvimento econômico.

Quanto aos recursos a serem mobilizados para tal intento, os fluxos de capitais, que são de interesse central para essa pesquisa, juntamente com o acesso a mercados para produtos africanos, são identificados como eixos estratégicos. Os líderes africanos identificam a necessidade de preencher uma lacuna da ordem de $12 \%$ dos seus PIBs com fluxo de capitais, dos quais a maior parte deve vir de fora do continente, em forma de redução das dívidas, Assistência ao Desenvolvimento (ODA) e capitais privados (NEPAD, 2001). Em relação a esses últimos, pretende-se dar atenção à percepção dos investidores de que a África é um continente de alto risco, tratando da segurança dos direitos de propriedade e dos marcos regulatórios. Estão previstas medidas interinas de mitigação do risco, incluindo esquemas de garantia de crédito.

Institucionalmente, o plano progrediu, criando um Secretariado com sede na África do Sul, um Comitê Dirigente, um Comitê de Implementação, e cinco grupos de tarefa para identificar e implementar projetos nas áreas de enfoque do plano.

As interpretações sobre a importância da NEPAD variam desde as mais otimistas, como a comparação de José Flávio Sombra entre a NEPAD e o Plano Marshall $^{7}$, na medida em que ambos se pretendiam a costurar o "tecido esgarçado da economia e da política” de seus países alvo, até a visão dos pessimistas, que consideram o NEPAD como uma obra de retórica vazia.

A repercussão entre os governos e as instituições internacionais, em especial as financeiras, foi de entusiasmo. Mas as críticas surgiram por parte de intelectuais, movimentos sociais e ONGs dentro e fora da África.

No Brasil, uma das vozes mais polêmicas na crítica ao documento é Wolfgang Döpcke (2002), o qual afirma que a NEPAD toma a globalização como inevitável e não a questiona, aceitando o discurso hegemônico liberal e integrando-o à sua proposta. Ele caracteriza a NEPAD como uma "africanização das propostas liberais ocidentais”. Citando o jornal The Hearald, Wofgang Döpcke também critica a NEPAD caracterizando-a como um “'veículo neocolonial dos países imperialistas para explorar e subjugar’ o continente africano”. Ademais, ele afirma que, em relação

\footnotetext{
${ }^{7}$ Convém esclarecer que a NEPAD, ao contrário do Plano Marshall, não é obra de um programa massivo financiamento estrangeiro voltado à reconstrução do continente, mas sim um esforço interno/regional de auto-gestão.
} 
às medidas concretas e prioridades setoriais, o plano é convencional e as políticas de desenvolvimento semelhantes às de décadas passadas. Saraiva, no entanto, sugere como a melhor tônica de avaliação o otimismo cauteloso.

Diante dessas interpretações, um balanço que se pode fazer desses quase dez anos desde o lançamento da parceria é que seu principal legado provavelmente seja o espírito de auto-gestão que tomou os líderes e a população africana, em maior ou menor grau, a depender do país. Vizentini, citando o líder nacionalista tanzaniano, Julius Nyerere, afirma que “pela primeira vez a África está logrando certa autonomia para reorganizar-se com bases numa correlação de forças regionais” e é nisso que consiste o ineditismo da NEPAD.

\subsection{A Redescoberta da África:}

O mundo está acompanhado com a máxima atenção a reinserção internacional da África, assim afirma José Flávio Sombra Saraiva. Desenha-se no continente uma forte competição entre novos atores, que, ao invés de debilita-lo, tem aumentado sua margem de manobra nas relações internacionais.

Segundo Pio Penna Filho, a responsável pela redescoberta da África é, sem dúvida, a China. A aproximação entre China e África remonta ao fim dos anos 1980 e início dos 1990, quando o massacre da Praça da Paz Celestial (1989) resultou em um isolamento da China imposto pelo Ocidente. A África foi vista por Pequim, então, como uma alternativa para vencer o isolamento, na medida em que foi uma das poucas regiões do mundo que não se posicionou contra o massacre ${ }^{8}$. A contrapartida política, na visão dos países africanos, era a posição da China no Conselho de Segurança.

Apesar de a aproximação ter-se iniciado pela política ${ }^{9}$, a predominância da presença chinesa na África é na área econômica. Segundo Saraiva, a China desembarcou na África de forma estrutural: As empresas estatais chinesas foram pioneiras, mas a iniciativa privada e os atores subnacionais também têm importância

${ }^{8}$ Os governos de Angola e Moçambique chegaram a manifestar apoio ao ato.

${ }^{9}$ Vizentini afirma que combater a presença de Taiwan também foi um fator importante. Nesse momento, existiam alguns governos que ainda reconheciam o governo de Taipei. Mas a China viu nisso uma oportunidade. A política chinesa voltar-se-ia mais ao continente, desde que houvesse a garantia de não reconhecimento de Taiwan. 
significativa; as grandes obras de infraestrutura geram milhões de empregos ${ }^{10}$, favorecem o desenvolvimento econômico e ajudam na reconstrução após as guerras; os produtos chineses, extremamente baratos, permitem aos africanos o acesso a um consumo antes inimaginado; e a ajuda financeira chinesa, que em 2009 foi anunciada em um montante de US\$ 10 bilhões, possibilita aos africanos deixarem de solicitar os empréstimos do FMI e a serem mais seletivos com a ajuda Ocidental.(VIZENTI, 2010)

Além disso, algumas características da abordagem dos investimentos chineses se mostraram uma vantagem desse país na África: os chineses não hesitam em investir em áreas conturbadas; as petrolíferas chinesas dispõem-se a empregar grandes quantidades de dinheiro e trabalho para obter direitos de exploração e desenvolvimento em países com grandes riquezas energéticas; as empresas associamse indiferentemente a governos nacionais, empresas estatais ou privadas, a fim de estabelecer presenças locais de longo prazo, ainda que os países possam parecer pouco promissores de imediato; e a China não se preocupa com as objeções que os EUA ou outros países ocidentais possam fazer em relação à escolha de seus parceiros $^{11}$.

O ano de 2005 merece destaque em relação aos investimentos chineses na África. Nesse ano, desembarcaram no continente aproximadamente mil empresas chinesas e centenas de milhares de trabalhadores do mesmo país. A partir de então, a presença chinesa vem crescendo cada vez mais e as expectativas são de que, com a crise econômica internacional que vem se desenhando desde 2008, a China ganhe ainda mais espaço na África ${ }^{12}$.

A ousadia da China chega a “invadir” os espaços já consolidados dos ocidentais. A China adquiriu a petroleira suíça Addax Petroleum, que controlava poços na Nigéria, no Gabão e em Camarões; apresentou um projeto para construir um oleoduto no Quênia, que permitirá extrair o petróleo do Sudão; adquiriu direitos sobre o petróleo em Níger; e discute uma parceria com a britânica Tullow Oil para a

\footnotetext{
${ }^{10}$ Vale a ressalva de que muitas vezes a China emprega sua própria mão de obra e que haja algumas tensões localizadas.

${ }^{11}$ Essa postura, inclusive, alimenta a simpatia dos regimes africanos pela China.

12 Já em relação aos Estados unidos, a crise reduziu a margem de manobra desse país na África e frustrou a expectativa de que, a partir do Governo Obama, os temas econômicos ganhassem mais importância.
} 
exploração da bacia petrolífera descoberta no Lago Alberto, em Uganda. (BOSCO, 2010)

João Bosco Monte aponta duas apostas mais para as iniciativas chinesas: obter a exploração de petróleo na Nigéria, quinto fornecedor de petróleo dos Estados Unidos, controladas até agora por Shell, ExxonMobil, Chevron, numa operação em torno de 30 bilhões de dólares; e a exploração de uma grande bacia petrolífera em Gana, que depende de um acordo com as autoridades locais.

Um dos grandes diferenciais da China na África é o volume da demanda por matérias primas, minerais e petróleo ${ }^{13}$, para fomentar seu crescimento acelerado. Atualmente, dos dez principais fornecedores de petróleo à China, quatro estão na África, quais sejam, Angola, Sudão, Congo-Brazzaville e Líbia. Segundo Vizentini, Angola tornou-se o maior fornecedor de combustível para a China, superando a Arábia Saudita. E mais, ao ritmo atual de crescimento, a China deve aumentar ainda mais seu déficit energético ${ }^{14}$, o que significar um grande potencial para a África.

Números publicados no artigo "China ups the Ante in Africa” e citados por Amaury Porto de Oliveira (2008) dão ideia da magnitude da presença chinesa na África. Os investimentos, tanto em comércio, manufaturas e processamento, exploração de recursos naturais, comunicação e desenvolvimento, são da ordem de US\$ 6,27 bilhões. O comércio cresceu de US\$ 11 bilhões em 2000, para US\$ 50 bilhões em 2006. Já os projetos são 720, em 49 países africanos, além de outros 58 em andamento, todos financiados por meio de empréstimos preferenciais. Além disso, um Fundo de Desenvolvimento China-África será criado para financiar companhias chinesas que desejarem abrir novos negócios na África (OLIVEIRA, 2008:87).

Existem, porém, muitas críticas à atuação chinesa na África, tanto quanto ao fato de a maioria das balanças comerciais dos países serem deficitária, quanto à qualidade dos produtos, ao endividamento causado pelos empréstimos chineses e à indiferença e até proteção a regimes violadores dos direitos humanos. Apesar disso, a repercussão da atuação chinesa entre a maioria dos países africanos é positiva, sendo exaltada, principalmente quando comparada à europeia.

\footnotetext{
${ }^{13}$ Ainda que a principal fonte de energia da China seja o carvão, este país asiático é o segundo consumidor mundial de petróleo.

${ }^{14}$ Em 1993, a China deixou de ser autossuficiente em petróleo.
} 
De acordo com Oliveira, o principal rival da China na África são os Estados Unidos. Apesar de este país não ter uma grande tradição de trabalho diplomático com a África, nos últimos anos os Estados Unidos veem investindo na abertura de embaixadas de grande porte em algumas capitais africanas. A explicação está na luta contra o terrorismo, na medida em que nessas embaixadas têm sido instalados poderosos centros de escuta da CIA.

No plano dos investimentos, a estratégia americana para a África, chamada de More than Humanitarism, privilegia o pragmatismo em detrimento do humanitarismo e tem como linhas gerais a disputa por recursos minerais, a ampliação e diversificação no campo da energia, cooperação com os governos democráticos e ocupação de espaços na luta contra o terrorismo.

O foco do governo americano na disputa pela “nova partilha” da África é competir com as ex-metrópoles, em especial França ${ }^{15}$ e Inglaterra, e com a China. Em relação a essa última, porém, as hesitações dos EUA têm dado oportunidade para a China ganhar espaço. Um exemplo é o caso da Guiné Equatorial. Empresas americanas exploravam petróleo do território há anos, mas as relações políticas entre Washington e Malabo não decolavam. Em 2005, o presidente Mbasogoto foi convidado a visitar Pequim, a partir de quando a China tornou-se uma parceira comercial importante da Guiné Equatorial, com crescimento das exportações de petróleo de US\$ 374 milhões em 2003 para US\$2,5 bilhões em 2006 (OLIVEIRA, 2008)

No que compete à Índia, apesar de a redescoberta da África ser um fenômeno típico dos anos 2000, este país tem atuação de destaque no continente desde a década de 1990. Um exemplo disso é a cooperação econômica, capitaneada pelo programa de cooperação técnica e econômica indiano (ITEC), o qual foi responsável por um projeto para indústrias de pequena escala no Zimbábue, Nigéria, Senegal, Tanzânia, Uganda, Quênia, Gana e Etiópia. Mais recentemente, o Exim bank indiano lançou o programa Focus África para promover encontro de empresários indianos e para a criação de centros empresariais. (VIZENTINI, 2010)

O interesse da Índia, assim como o da China, está calcado na necessidade de

\footnotetext{
${ }^{15}$ Saraiva traz o dado de que a França é a maior investidora individual no conjunto da economia africana.
} 
recursos energéticos, matérias primas, produtos agrícolas, mercados e espaço para investimentos. Tudo isso resulta do forte crescimento econômico da Índia. Nesse sentido, segundo Oliveira (2008), o que diferencia a Índia da China é a abordagem de suas empresas. Enquanto esta última é mais avessa ao risco, a primeira adota uma estratégia que lhe dá maior integração nos mercados domésticos. Isso significa que a China opta por uma estratégia de maior controle da cadeia produtiva, tanto para cima como para baixo, o que gera o aparecimento de enclaves e menores efeitos de difusão dos benefícios dos investimentos (OLIVEIRA, 2008:76)

Outra diferença entre os dois emergentes da Ásia é que o esforço indiano é conduzido basicamente por forças empresariais, enquanto o chinês é resultado da junção dos níveis governamental, partidário e empresarial. O resultado é que a China obtém melhor desempenho.

A África do Sul, apesar de não ser um investidor estrangeiro ao continente como os acima relatados, tem atuado como um ator externo nos países africanos individualmente e compete com as potências e os países emergentes que disputam espaço na África. A África do Sul é a maior economia africana, não apenas por seu tamanho, mas também por ser um hub de distribuição de bens importados para o resto do continente. Porém, a despeito de a economia sul-africana ser moderna e possuir uma boa base industrial, ela ainda está atrás de países como China, Índia, Rússia e Brasil. Mesmo assim, Vizentini qualifica a África do Sul como líder da África Negra e compara a atuação desse país em sua área de inserção imediata com a do Brasil em relação á América do Sul (Vizentini, 2007).

De fato, a África do Sul pós-Apartheid, não apenas emerge como o país mais desenvolvido da África, como passa a ter um protagonismo considerável na política internacional, tanto pleiteando uma vaga no Conselho de segurança das Nações Unidas, quanto formando alianças com os demais emergentes, como no IBAS e, mais recentemente, integrando o BRICS.

No âmbito regional, a SADC - Comunidade para o Desenvolvimento da África Austral é o locus onde essa proeminência da África do Sul é exercida. Se por um lado a entrada da África do Sul no arranjo regional consiste um desafio, visto que 
as disparidades afloram nas diferenças de $\mathrm{PIB}^{16}$, no enorme superávit comercial em relação aos outros países do bloco e na dependência que os outros membros têm em relação à infraestrutura de portos e estradas fornecidos pela África do Sul, por outro lado sua adesão ao bloco adicionou valor à organização, incrementando os vínculos com a economia global.

Os atores externos apresentados até agora não representam a totalidade dos países que investem e buscam espaço na economia africana que renasce. Podem ser mencionados também os países europeus, que não foram analisados por serem atores tradicionais no continente, presentes desde o período colonial, e que por essa razão não são exatamente protagonistas no processo de redescoberta da África ${ }^{17}$.

Além disso, o Brasil, que converge a sua ascensão como país emergente com o renascimento africano, encontra nesse continente espaço para expandir seus investimentos e é um ator que se destaca na “corrida” pela África. Uma análise mais detalhada da redescoberta da África pelo Brasil será feita no próximo capítulo.

\footnotetext{
${ }^{16}$ Na virada do século, o PIB total da SADC era de aproximadamente US\$ 180 bilhões, dos quais a África do Sul sozinha era responsável por US\$130 bilhões.

${ }^{17}$ Apesar de seus espaços tradicionais serem cada vez mais ameaçados pela chagada dos novos atores.
} 


\section{A POLÍTICA EXTERNA BRASILEIRA PARA A ÁFRICA SOB O GOVERNO LULA:}

Após séculos de intensos contatos entre a África e o Brasil, seja pelo comércio de escravos, seja pela influência cultural dos escravos africanos na formação da cultura brasileira, as relações entre os dois lados do Atlântico ${ }^{18}$ foram silenciadas por quase um século.

Apesar de haver divergências teóricas ${ }^{19}$, a Política Externa Independente PEI (1961-1964) é um marco para o retorno aos contatos entre a África e o Brasil. Com ela, o Brasil definiu uma política específica direcionada à África, posicionandose a favor da descolonização e identificando aspirações comuns entre o Brasil e a África nas áreas de desenvolvimento econômico, defesa dos preços das matérias primas, industrialização e desejo de paz. Essa posição pode ser considerada um marco, pois os governos anteriores adotavam uma posição de alinhamento ou, pelo menos, não confrontação com as potências coloniais. Além disso, a orientação da política externa brasileira para a África atendia a novas necessidades geradas pelo processo de industrialização das décadas anteriores.

A retomada de uma política africanista por parte do Itamaraty consolida-se durante o Pragmatismo Responsável e Ecumênico (1974-1979). Nesse sentido, a vanguarda brasileira no reconhecimento da independência de Angola, em 1975, foi um marco. Com isso, deu-se "consistência prática”, nas palavras de Saraiva, ao discurso que se vinha gestando durante a PEI. A África, nesse período, foi identificada como área de virtual interesse econômico e estratégico ${ }^{20}$ e esse foi um tempo tido como “os anos dourados” da política africana do Brasil (SARAIVA, 1999). Esse período marca a instalação da primeira empresa brasileira na África

\footnotetext{
${ }^{18}$ Em diversas obras, Saraiva utiliza a metáfora de olhares transatlânticos para representar as relações Brasil-África. Ver, por exemplo, SARAIVA, José Flávio Sombra. A África na Ordem Internacional do Século XXI: mudanças epidérmicas ou ensaios de autonomia decisória? Revista Brasileira de Política Internacional. Vol. 1, n 51, 2008, p. 87-104.

${ }^{19}$ Enquanto para Amado Cervo, em História da Política Exterior do Brasil, o discurso anticolonialista e de autodeterminação dos povos não era condizente com apenas a abstenção na ONU nas questões de Angola e da Argélia, para Saraiva, em Olhares Transatlânticos: África e Brasil no Mundo Contemporâneo, 1961, ano de início da PEI, é um ano chave para o reencontro do Brasil com a África. ${ }^{20} \mathrm{O}$ caráter estratégico estava em ser uma área em que o Brasil poderia ter, com maior facilidade, alguma influência regional, porque o Brasil necessitava da simpatia diplomática dos africanos para legitimar a expansão do Mar Territorial para 200 milhas, além da necessidade de diversificar os parceiros para suprir as dificuldades do setor energético, causada pelas crises do petróleo de 1973 e 1979, e para dar vasão à renda concentrada do "Milagre Econômico”.
} 
negra.

Na década de 1980, porém, as dificuldades em manter o relacionamento promissor da década de 1970 foram evidentes. O modelo desenvolvimentista, que orientou a diversificação de parceiros da política externa brasileira e a reaproximação do Brasil em relação à África, dava sinais de seu esgotamento (CERVO, 2002). Tanto a África como o Brasil foram afetados pela crise da dívida, sendo que no caso da África o impacto foi maior e agravado pelos planos de ajuste do FMI e pelos conflitos da Guerra Fria. Ainda assim, algumas iniciativas pontuais foram engendradas, como a visita do primeiro presidente brasileiro ao continente, em 1983, quando Figueiredo viajou para Nigéria, Senegal, Guiné-Bissau, Senegal e Cabo Verde.

\subsection{As escolhas seletivas dos anos 1990 e a preparação para o momento atual:}

Na década de 1990, as relações do Brasil com a África, que havia passado por momentos de grande prosperidade nas décadas anteriores, entra em declínio, o que foi denominado por Saraiva de "olhar sonolento". (SARAIVA, 1999) O volume de comércio retroagiu a cifras dos anos 1950/1960. (SARAIVA, 2010)

Esse declínio é dado por contextos desfavoráveis em ambos os lados do Atlântico. Na África, a crise profunda, calcada no endividamento externo, na crise social das epidemias e nas conturbadas transições políticas para a democracia, que em muito casos desembocaram em violentas guerras civis, faziam com que o continente se marginalizasse cada vez mais do sistema internacional.

Já o Brasil passou por uma reorientação da sua política externa, que o afastou de sua tradição desenvolvimentista para privilegiar características do Estado Normal $^{21}$ e as relações com os países desenvolvidos. A ênfase passou a ser nas relações verticais Norte-Sul, em detrimento das relações horizontais Sul-Sul, na

\footnotetext{
${ }^{21}$ De acordo com Amado Cervo, em História da Política Exterior do Brasil, o Estado Normal seria caracterizado pela subserviência ao centro do capitalismo, pela alienação do "núcleo robusto da economia nacional", pela transferência de renda ao exterior e regressão da nação às "funções da infância social” (CERVO, 2002). Esse tipo de Estado caracterizou os governos latino-americanos da década de 1990, principalmente na Argentina, Brasil, Peru, Venezuela e México.
} 
medida em que a orientação da política externa brasileira desse período era de adesão ao neoliberalismo e a inserção total na globalização. Além disso, contribuíram para o declínio comercial que se seguiu a retirada do Estado do financiamento das exportações e a necessidade de importar petróleo da Argentina, no intuito de equilibrar os pesos econômicos no interior do Mercosul. (VIZENTINI, 2010)

José Vicente de Sá Pimentel (2000) divide a visão dos formuladores da política externa brasileira para a África naquele momento entre nostálgicos e catastrofistas $^{22}$. Os primeiros enfatizavam as responsabilidades históricas ${ }^{23}$ e comparavam os anos 1990 com os anos 1970, exaltando os últimos em detrimento dos primeiros. Por outro lado, os catastrofistas davam ênfase ao quadro de crise no continente, tendo isso como um fator que impossibilitava o diálogo com o continente. Esse último grupo foi chamado por Saraiva de afro-pessimistas, os quais, para esse mesmo autor, dominaram o processo decisório brasileiro.

Apesar das visões extremas, a política externa brasileira para a África nos anos 1990 fez escolhas seletivas, quais sejam, África do Sul, Angola, ZOPACAS e CPLP. Pimentel justifica a seletividade por considerar que uma política africana não seria o mais adequado diante de uma diversidade tão grande entre seus países.

A África do Sul é reconhecida pelo valor estratégico da sua posição geográfica e por ser o principal e o mais tradicional parceiro do Brasil no continente. Angola, que na década de 1990 ainda não tinha seus conflitos remanescentes da independência solucionados, destaca-se pela presença brasileira na Missão de Paz na ONU naquele país, pela presença de investimentos brasileiros, mesmo em temos de guerra, além do relacionamento privilegiado ${ }^{24}$ herdado do fato de o Brasil ter sido o primeiro país a reconhecer a independência angolana.

\footnotetext{
${ }^{22}$ Para análise mais detalhada, ver: PIMENTEL, José Vicente de Sá. Relações entre o Brasil e a África Sub-Saariana. Revista Brasileira de Política internacional. Vol. 43, n 1, jan-jun 2000.

23 É interessante notar quanto aos nostálgicos que o apelo aos laços culturais e à dívida histórica é uma postura recorrente, mesmo que entre grupos minoritários no processo decisório, em momentos em que a política africanista brasileira sofre retrocesso ou perde o caráter pragmático-econômico.

24 Muitos autores, em especial os acadêmicos estrangeiros, criticam a ideia de relacionamento privilegiado do Brasil com Angola em função do reconhecimento da independência. Estes baseiam seus argumentos no montante dos investimentos, nos fluxos de comércio e no montante da ajuda humanitária e para o desenvolvimento que países como Portugal, por ser ex-metrópole, e EUA, por ser a grande potência saída da Guerra Fria, destinam a Angola, os quais comparados com o volume brasileiro realmente são bastante superiores. Porém, a expressão utilizada foi baseada em Saraiva (1999) e considera que em relação à posição que o Brasil ocupavam na distribuição de poder mundial e na capacidade de influência naquele país nesse período, realmente o Brasil passou a ocupar uma posição privilegiada.
} 
Em relação à ZOPACAS, houve uma retomada gradual da operacionalização. A Zona, apesar de ter sido formalizada em 1986, ficou relativamente esquecida nos anos seguintes, mas, com a revitalização, reuniões foram realizadas em 1990, 1994 e 1998. Por fim, a CPLP, que apesar de sua forma um pouco frouxa, no dizer de Saraiva, vem se consolidando como âmbito de promoção da cooperação entre os países.

A despeito da seletividade que caracterizou o período, cada um dos três governos da década de 1990 teve suas peculiaridades em relação à África e que merecem ser analisadas.

A começar por Fernando Collor, que apesar de ter dado início ao afastamento mais efetivo em relação à África e à redução do corpo diplomático brasileiro no continente, visitou a África em 1991, além de o governo brasileiro ajudar na estruturação da Marinha de guerra da Namíbia, no contexto de seu processo de independência. Em relação à visita de Collor ao continente, Saraiva afirma trata-se de uma rendição do presidente à força do nacionalismo e de uma tradição diplomática brasileira de diversificação de parceiros.

Com Itamar Franco, por outro lado, a política africana tem um suspiro de engajamento. É no governo Itamar que a ZOPACAS é reativada e que a CPLP ${ }^{25}$ realiza seu Encontro de Chanceleres de Língua Portuguesa. Vizentini destaca como mais importante nesse governo o apoio bilateral e multilateral, via ONU, ao processo de paz e reconstrução em alguns países, como, por exemplo, Angola. Convém observar também que a maior parte das escolhas seletivas que vão caracterizar os anos 1990 desenha-se no governo Itamar Franco.

Já Fernando Henrique Cardoso - FHC - tem abordagens diferentes em relação à África ao longo de seus dois governos: em um primeiro momento, com a África ocupando um lugar modesto e em um segundo, ao longo do segundo mandato, com certa inflexão, que seria qualitativamente aprofundadas pela política externa do governo Lula. As ações que se destacam são a participação mais ativa do Brasil em missões de paz da ONU, as quais a maioria era na África, visitas presidenciais, ainda

25 Utiliza-se aqui CPLP como uma apropriação do que viria a se tornar a comunidade institucionalizada em 1996, na medida em que só foi criada oficialmente no governo Fernando Henrique Cardoso. O mérito da iniciativa e de boa parte das negociações, contudo, fica com Itamar Franco e com José Aparecido de Oliveira, embaixador brasileiro em Portugal à época. 
que mantendo a seletividade, e a assinatura do Acordo Quadro África do SulMercosul.

Vizentini destaca que, com a crise do Real e a mudança da postura de FHC em relação à globalização, que, em seu discurso, passa de “inevitável” para “assimétrica”, o Brasil e os Estados africanos passam a ter maior convergência na diplomacia mundial e nos foros multilaterais, principalmente os econômicos. Essa mudança no discurso e nas atitudes parece ser o ponto que mais se aproxima da política externa do governo seguinte. Convém, contudo, não sobrevalorizar a importância dessa inflexão, tendo em vista que a grande retomada da política africanista brasileira se dá no governo Lula, como será visto no próximo subitem.

\subsection{A Política Externa do Governo Lula para a África:}

A ascensão de Lula ao poder, em 2003, representa, nas relações do Brasil com a África a elevação da política africanista brasileira a um “estado de arte” (SARAIVA, 2010). Essa abordagem nas relações Brasil-África insere-se em um contexto de mudanças substanciais na política externa brasileira, como um todo, principalmente, em relação ao governo anterior. Nesse subitem, serão apresentadas as mudanças que o novo governo aportou para as relações exteriores do Brasil e, em seguida, suas implicações para a política africanista do país e o que ela tem de novidade em relação a outros períodos.

De acordo com Amado Luiz Cervo (2008), a política externa do governo Lula enquadra-se no paradigma logístico. Por esse paradigma o Estado passa a transferir à sociedade as responsabilidades do Estado empresário, que caracterizava o paradigma desenvolvimentista. O Estado foca em dar apoio logístico aos empreendimentos, preferencialmente, mas não exclusivamente, ao privado, com o fim de robustecê-lo em termos comparativos internacionais. A interdependência com o mundo globalizado, nesse caso, opera-se pela agregação dos empreendimentos nacionais às cadeias produtivas internacionais e por meio de investimentos diretos no exterior.

Apesar de a imprensa caracterizar Lula como esquerda responsável por ele guardar heranças do neoliberalismo, como responsabilidade fiscal e estímulo aos investimentos estrangeiros, Amado Cervo afirma que ele aprofundou o paradigma 
logístico, que havia apenas sido iniciado por Fernando Henrique Cardoso.

De fato, Lessa e Cervo (2010) apontam a internacionalização da economia brasileira como um dos êxitos ${ }^{26}$ da política externa brasileira do governo Lula, considerando isso um salto qualitativo em direção a um processo de desenvolvimento maduro. Um dado que demonstra a importância dessa mudança é o Brasil ser o país que tem a economia mais internacionalizada entre o BRIC ${ }^{27}$ (LESSA \& CERVO, 2010), que é justamente a reunião das economias emergente que devem, até 2050, estar entre as maiores economias do mundo.

Além da abordagem logística do Estado brasileiro, outra característica da política externa do Governo Lula é a opção pelas relações Sul-Sul. Nesse sentido, Tullo Vigevani e Gabriel Cepaluni afirmam que uma das principais mudanças de Fernando Henrique Cardoso para Lula é a diferença de percepção e ideologia desses líderes e de suas equipes a respeito dos constrangimentos e das possibilidades da ordem internacional vigente.

A tese postulada por eles é de que

\begin{abstract}
a política externa de FHC defendia a ideia de "autonomia pela participação" no sistema internacional, contrapondo-se à busca da "autonomia pela distância", que prevaleceu até o final do governo Sarney (VIGEVANI; OLIVEIRA, 2004; FONSECA JR., 1998), enquanto Lula da Silva procurou inserir o Brasil no cenário mundial acentuando formas autônomas, diversificando os parceiros e as opções estratégicas brasileiras... enfatizando a cooperação Sul-Sul para buscar maior equilíbrio com os países do Norte, realizando ajustes, aumentando o protagonismo internacional do país e consolidando mudanças de programa na política externa. (VIGEVANI; CEPALUNI, 2007)
\end{abstract}

Essa estratégia do governo Lula foi batizada pelos autores de "autonomia pela diversificação”.

A política africanista brasileira do governo Lula insere-se tanto na abordagem Sul-Sul, como na do Estado Logístico. Para Saraiva (2010), a política externa para a

\footnotetext{
${ }^{26}$ Esses autores apontam dois fracassos, que são as negociações comercias no âmbito da OMC, tendo em vista que a Rodada Dora não conseguiu, até o fim do governo, chegar a um acordo, e a demanda de reforma do Conselho de Segurança. Por outro lado, eles também apontam sucessos notáveis, quais sejam, a internacionalização da economia brasileira, a mediação de conflitos internacionais e a coalizão entre os países emergentes.

27 Segundo os autores, o Brasil se destaca tanto como receptor de empresas estrangeiras quanto na expansão externa das empresas e investimentos brasileiros.
} 
África no governo Lula ganhou bases mais permanentes, próximas a uma política de Estado. O mesmo autor a caracteriza como uma mistura muito bem equilibrada de idealismo com realismo.

No contexto externo, uma nova visão da globalização por parte tanto do Brasil quanto da África, mais distante da visão neoliberal e mais próxima da interdependência real, segundo Cervo (2008), dá a tônica da aproximação. Já internamente, existe uma convergência de momentos que favorecem a aproximação. Na África, como foi visto, a primeira década do século XXI foi de crescimento a taxas relativamente altas, restruturação dos Estados e das sociedades e fim de conflitos. No Brasil, o crescimento econômico da década também foi significativo e ganhou ares mais sofisticados que em outros períodos pela associação de programas de sociais, que melhoraram a distribuição de renda no país, com o caráter logístico do Estado, o qual criou condições de expansão da economia nacional e que encontra na África um campo de atuação para esse Estado mais maduro economicamente.

Vizentini (2010) apresenta algumas visões a respeito da política africana do governo Lula:

a) Dimensão solidária - Por essa visão, a aproximação com a África seria uma extensão internacional do programa social do governo.

b) Diplomacia de prestígio - Por essa visão, a política não teria substância e, portanto seria desperdício de tempo e dinheiro.

c) Diplomacia de Negócios - Segundo essa visão, a política africana do governo Lula seria uma espécie de imperialismo soft, que se diferenciaria da presença chinesa apenas em forma e intensidade.

Muitas foram as críticas de que a aproximação do Brasil com a África tinha uma conotação poética ou lírica, mas tanto o ex-presidente Lula, quanto o exministro Celso Amorim expressam em seus discursos e nas ações do próprio Estado brasileiro que as relações com o continente são baseadas em interesses concretos e que a África é uma prioridade para o Brasil. A conotação não é nem paternalista, reproduzindo o discurso de expiar a culpa pelo passado colonial, nem de exploração, visando apenas a exploração das grandes reservas de recursos naturais; ela é a construção de uma verdadeira parceria. (SILVA, 2009)

Os interesses concretos a que se refere o discurso oficial podem ser vistos no 
crescimento do comércio de US\$ 5 bilhões, em 2002, para US\$ 26 bilhões, em 2008 (AMORIM, 2009). Além da área comercial, as relações têm desempenho notável na área de investimento, principalmente na área petrolífera, mineração, infraestrutura e serviços, cooperação em saúde, tecnologia, diplomacia, segurança e defesa. Vizentini, porém, afirma que os pilares mais importantes dessa recente aproximação são o estratégico e o econômico, no sentido de que são de extrema relevância para a projeção mundial brasileira.

Dentro do pilar econômico, as relações comerciais ${ }^{28}$ apresentam resultados quantificáveis que demonstram a importância da aproximação do continente africano. Até 2008, o Brasil era o $11^{\circ}$ parceiro da África e, entre os em desenvolvimento, ficava atrás apenas da China e da Índia. Em relação ao governo anterior, os resultados da mudança na importância da África ficam patentes: entre 1995 e 2002 as exportações para a África cresceram 76\%, enquanto entre 2003 e 2009 cresceram quase 400\%; já o desempenho das importações foi um pouco mais modesto, com crescimento de $260 \%$ no primeiro período, contra 326\% no segundo. (MRE, 2010)

Convém ressaltar que a maior parte das exportações brasileiras é de manufaturados (MDIC,2009) e nisso consiste um dos pontos estratégicos do continente, uma vez que, historicamente, Amado Cervo (2008) ressalta que o poder de atração da África sobre os dirigentes brasileiros está justamente em ser um mercado para as manufaturas brasileiras, enquanto o primeiro mundo as rejeitava. Outro aspecto estratégico pode ser demonstrado no papel da África durante a crise internacional, quando, apesar de o fluxo de comércio ter reduzido, a redução das exportações para o continente foi bem menor que a queda das exportações totais do Brasil, o que resultou em um aumento da participação dos países africanos na absorção de produtos brasileiros. (MRE, 2010)

Esses resultados não são apenas frutos da convergência de momentos favoráveis nos dois lados do Atlântico; o Brasil fez investimentos diplomáticos de vulto, onde, por sinal, reside boa parte das críticas dos céticos em relação à aproximação com a África. Foram realizadas 28 visitas do presidente Lula ao longo

\footnotetext{
${ }^{28}$ Quanto ao outro pilar das relações econômicas, os investimentos diretos serão analisados de forma detalhada no capítulo seguinte, que será dedicado exclusivamente a eles.
} 
de todo o seu mandato e $67^{29}$ visitas do Ministro Celso Amorim (MRE, 2010), sendo que boa parte das visitas do presidente foram acompanhadas de grupos de empresários, representantes dos mais diversos ministérios e intelectuais. O número de postos abertos no continente cresceu e diversos postos que haviam sido fechados foram reabertos. O Governo brasileiro perdoou a dívida de alguns países africanos, em atendimento às Metas do Milênio, como no caso de Moçambique, em que o perdão chegou a 95\% da dívida (VIZENTINI, 2010). Além disso, na própria estrutura do Itamaraty houve modificações, o antigo Departamento de África e Oriente Médio foi dividido, dando lugar a um departamento exclusivo para o continente africano.

Em contrapartida, foram 48 visitas de chefes de Estado e de Governo africanos e 66 visitas de ministros de negócios estrangeiros (MRE, 2010), número quase idêntico ao de visitas de Celso Amorim, o que demonstra grande reciprocidade dos Estados africanos. Já em relação aos postos de países africanos abertos em Brasília, apenas entre 2003 e 2006, o número saltou de 16 para 25 (VIZENTINI, 2010). Na área política, o Brasil obteve o apoio dos países da CPLP em diversas candidaturas brasileiras a cargos em organismos internacionais, como Conselho de Segurança das Nações Unidas e Diretor-Geral da FAO (MRE, 2010).

No que diz respeito à cooperação internacional, outra forma de investimento diplomático, relativamente barata em termos de custo benefício ${ }^{30}$, merece destaque o fato de o Brasil ter passado da categoria de país receptor de cooperação para doador. Em grande parte, essa mudança está associada às investidas em direção à África. Instituições brasileiras como Embrapa, SENAI e Fiocruz são atores de relevo nesse processo. O foco da cooperação está nos Países Africanos de Língua Portuguesa (PALOP), os quais recebem $74 \%$ da cooperação brasileira destinada à África (VIZENTINI, 2010), com destaque para Moçambique, que é o segundo receptor de cooperação brasileira no mundo, atrás apenas do Haiti.

Um exemplo emblemático de como o Brasil projeta sua influência mundial por meio dos investimentos diplomáticos na África é o caso dos biocombustíveis. Em

\footnotetext{
${ }^{29}$ Em número de visitas do Ministro das Relações Exteriores, a África ficou atrás apenas da Europa, com 70 visitas.

${ }^{30} \mathrm{O}$ montante que o Brasil destina à cooperação é elevado, porém os benefícios em termos políticos, comerciais e diplomáticos, são desproporcionalmente superiores.
} 
2008, o Brasil defendeu a importância da produção de biocombustíveis como oportunidade de desenvolvimento para as nações africanas e, de fato, o Brasil tem desenvolvido projetos de cooperação nessa área em países africanos, em especial, por meio da cooperação trilateral com países desenvolvidos. Isso, porém, insere-se no contexto do projeto brasileiro de transformar os biocombustíveis em commodity, o que seria bastante vantajoso para a economia brasileira.

Apesar de estar motivado por interesses bastante pragmáticos, isso não invalida os benefícios mútuos da aproximação do Brasil com a África, na medida em que os países receptores da cooperação se beneficiam também da dotação de infraestrutura resultante da cooperação, a formação de know-how nacional e da abertura de novas possibilidades de áreas de onde possa auferir o desenvolvimento econômico. No atual ambiente internacional, é importante para o Brasil ter parceiros fortes, que colaborem na construção de uma ordem internacional multipolar (VIZENTINI, 2010).

Outro campo de atuação que merece destaque na atuação do Brasil na África é a coalizão do grupo IBAS entre Índia, Brasil e África do Sul, que, além de coordenar posições em foros multilaterais e ter o Fundo IBAS como importante instrumento de atuação na ajuda ao desenvolvimento de países africanos, principalmente, mas também de outros continentes, tem a importância estratégica de unir os oceanos Atlântico e Índico, por meio de seus membros, criando uma nova rota de ligação do Brasil com a Ásia.

Na área de segurança, o Brasil tem atuado, por meio da CPLP e de sua presidência nos trabalhos da Comissão para a Construção da Paz da ONU, com vistas à solução da crise em Guiné-Bissau. A revitalização da ZOPACAS, em um contexto de reativação da $4^{\text {a }}$ Frota americana no Atlântico Sul, com o Plano de Ação de Luanda envidando esforços no reforço à cooperação na região, mostra-se de grande importância, mas ainda não atingiu todo o seu potencial na visão de Vizentini (2010).

Já Cúpula América do Sul-África constitui um mecanismo de cooperação entre duas regiões prioritárias para a política externa do governo Lula, além de congregar representantes da Unasul e da UA, e encontra suas origens na articulação entre Nigéria e Brasil. Não por acaso, esses dois países co-presidem o órgão executivo do mecanismo, a ASACOF. Também no âmbito sul-americano, a SACU e 
o Mercosul firmaram acordo de comércio preferencial em 2008, o qual está em tramitação no Congresso Nacional brasileiro. Além disso, o Egito firmou Acordo de Livre-Comércio com o Mercosul e Marrocos firmou acordo-quadro.

Mas, o que há de novo nessa política? Em que ela difere da intensa aproximação entre Brasil e África na década de 1970? De fato, as semelhanças são muitas. O Brasil, assim como na atual década, passava por uma fase de grande crescimento econômico, a aproximação era impulsionada pelo pragmatismo (Pragmatismo Responsável e Ecumênico), e esta se converteu em atitudes concretas, como o reconhecimento de Angola e o aumento do fluxo de comércio.

Contudo, Saraiva (2010) aponta seis características para demonstrar que não se trata de uma reedição do passado. A primeira é o fato de haver uma estratégia coordenada, baseada no interesse nacional e no de seus protagonistas, entre eles empresários incumbidos da expansão do capitalismo brasileiro. A segunda consiste em uma mudança conceitual, mas também prática, em que os arredores a leste do Brasil são reativados como uma das regiões preferíveis para contato, cooperação e comércio. A outra característica é a revisão do discurso culturalista em prol de uma abordagem mais estrutural e pragmática ${ }^{31}$. A quarta característica diz respeito à opinião pública, de forma que a atual política tem mais publicidade e é legitimada por consenso político e social, por meio de instituições como o Parlamento, universidades, empresas e opinião pública em geral. A quinta característica é o fato de o Brasil estar trabalhando em um ajuste Sul-Sul de forma a possibilitar a construção de uma plataforma comum de interesses entre o Brasil e a África. Por fim, a sexta característica é o repudio a relações meramente instrumentais, como ocorria antes.

Essa última característica, juntamente com a primeira, talvez sejam as mais relevantes, na medida em que na década de 1970 as relações eram fortemente motivadas pela escassez energética do Brasil, de forma que, à medida que o país ia adaptando sua matriz energética a outras fontes e que os preços do petróleo iam reduzindo, as relações com a África ficavam menos estratégicas e mais negligenciadas. Já com relação à estratégia coordenada entre governo e atores

\footnotetext{
${ }^{31}$ Quando Saraiva fala em discurso culturalista do passado, provavelmente se refere à década de 1960 e não 1970.
} 
econômicos privados, nisto consiste a base do Estado logístico e a vertente que mais interessa a essa pesquisa, pois materializa-se nos investimentos diretos brasileiros no continente. 


\section{OS INVESTIMENTOS BRASILEIROS NA ÁFRICA:}

A presença de firmas estrangeiras no setor produtivo brasileiro sempre foi significativa, sendo um dos países que tinha maior percentual entre os em desenvolvimento. Esse quadro, porém tem se invertido nos últimos anos: em 2006, o volume de investimentos externos diretos efetuados do Brasil para o exterior foi, pela primeira vez na história, maior que o de investimentos recebidos, atingindo o recorde de US\$ 32,3 bilhões (KPMG, 2008:4). Essa marca colocou o Brasil na 12a posição entre os maiores investidores do mundo, na frente inclusive da China (KPMG, 2008:6).

De acordo com Sérgio Amaral (2007), o Brasil está no terceiro momento da internacionalização da sua economia:

O primeiro foi a liberalização do comércio
internacional, em fins dos anos 1980 e início dos 1990.
O segundo, a abertura da economia aos investimentos
externos, em meados dos anos 1990. Por fim, mais
recentemente, em ritmo cada vez mais acelerado, é a
vez da internacionalização das empresas.

Segundo esse mesmo autor, nessa fase, não se trata mais de abrir a economia aos capitais estrangeiros, mas sim realizar investimentos em mercados externos. $\mathrm{Na}$ década de 1990, a abertura abrupta da economia, a interrupção do processo inflacionário e a reestruturação do setor produtivo do país, em grande parte, fruto da exposição à concorrência externa, fizeram o trabalho inicial de romper o quadro de isolamento mundial em que vivia a economia do país. Hoje, observa-se um claro amadurecimento da ação externa das empresas brasileiras.

A atuação dessas empresas no exterior não é, contudo, um fenômeno que se inicia só na década de 1990. Desde a década de 1960 e 1970 existem empresas brasileiras atuando em outros países. As pioneiras foram a Petrobras, as companhias de comercialização e os bancos, seguidos, na década de 1980, pelas empresas de engenharia e construção civil, que reagiam à crise financeira do Estado brasileiro. Nesse contexto, insere-se a instalação da Petrobras e da construtora Norberto Odebrecht em Angola, que foi o caso pioneiro na África.

Na década de 1990, o perfil das empresas que se internacionalizavam no Brasil eram as empresas produtivas, que buscavam os mercados externos para proteger-se dos empréstimos contraídos em moeda estrangeira ou insumos baratos para reduzir os custos. Atualmente, percebe-se que a nova fase resulta de um ganho 
de competitividade das empresas nacionais, buscando novos mercados pelos seguintes motivos:

Proximidade com o consumidor (Marco Pólo) [sic] ou ingresso em canais de distribuição (Sadía); algumas têm por objetivo uma elevação do patamar tecnológico mediante a presença em mercados mais competitivos, como é caso da Odebrecht, nos Estados Unidos; outras procuram posicionar-se na consolidação do setor (Gerdau); várias buscam contornar barreiras de acesso a mercados protegidos (Coteminas e Friboi nos Estados Unidos) [...] por fim, algumas começam a sair para posicionar sua marca, como é o caso da Natura na França. (AMARAL, 2007)

O setor que se destaca no perfil atual de empresas brasileiras internacionalizadas, tanto em escala global, quanto na África, é o de serviços.

De 2004 a 2006, o estoque de Investimento Externo Direto - IED brasileiro cresceu $14 \%$, principalmente em função da melhora da capacidade financeira das empresas brasileiras, da valorização do real e da estratégia de acumulação de ativos pelas firmas nacionais, com o objetivo de consolidar posição como global player.(BAUMANN, 2010) Renato Baumann ressalta que esses resultados são consequência de um cenário internacional favorável, muito mais do que de uma política específica voltada para os investimentos externos. Apesar disso, o mesmo autor destaca as iniciativas mais recentes do governo brasileiro em adotar uma política explícita para estimular os investimentos no exterior, com o fornecimento de crédito pelo BNDES para fusões e aquisições de grandes empresas ${ }^{32}$.

De fato, a forma de entrada dessas empresas em novos mercados tem sido prioritariamente via aquisição ou fusão, inclusive em estratégias para o futuro. Isso significa também que, apesar de a crise internacional ter revertido o cenário positivo de expansão das multinacionais brasileiras no exterior no ano de 2009, as empresas continuam dispostas a investir grandes somas de capital no exterior. Além disso, o fato de os efeitos da crise terem sido menos pronunciados no Brasil que nos países desenvolvidos colocou as empresas nacionais em uma posição mais confortável na compra de ativos no exterior. Em segundo lugar nas formas de entrada das empresas brasileiras em novos mercados, aparecem as alianças e parcerias e a instalação de

\footnotetext{
${ }^{32}$ Note-se que a política é seletiva: ela objetiva fortalecer e consolidar determinadas firmas domésticas como atores de destaque em setores específicos, tornando-as capazes de enfrentar a competição internacional.
} 
escritórios comerciais $^{33}$. (FDC, 2010)

No que diz respeito ao envolvimento do Estado no processo de internacionalização das empresas brasileiras, a elaboração de uma política mais ativa nessa área está baseada na premissa de que é importante ter atores de peso no cenário internacional composto por capital nacional. Nesse sentido, o Instituto de Estudos Estratégicos Internacionais - IEEI, de Portugal, caracterizou a estrutura organizacional e institucional do Brasil como sendo razoavelmente pouco fragmentada $^{34}$ (média/alta). A coordenação na estrutura interna do Estado brasileiro se dá no plano das grandes orientações estratégicas e no plano operacional, concentrando a competência em uma instituição de liderança operacional. Em termos práticos, isso significa que o Itamaraty fica responsável pela área política, principalmente cooperação, e de negócios, com a promoção comercial, realização de feiras e promoção de investimentos, em especial na área bilateral, enquanto o Ministério da Indústria e Comércio fica mais concentrado nos temas multilaterais, como a gestão da participação na OMC. A CAMEX - Câmara de Comércio Exterior fica na posição de dinamizar a coordenação, sendo composta por representantes de alto nível dos principais ministérios que atuam nessa área.

Na distribuição regional das multinacionais brasileiras, a África não aparece em posição muito privilegiada, correspondendo a 5,43\% do índice médio de regionalidade, ficando atrás de América Latina, Europa, Ásia e América do Norte, nessa sequência. Contudo, a África aparece com o terceiro maior índice de crescimento na regionalidade, com 16,39\% ${ }^{35}$. (FDC, 2010) O que tem influenciado empresas brasileiras investir na África é o potencial que o mercado do continente representa para os produtos e serviços brasileiros. Além disso, a possibilidade de se beneficiar dos acordos ACP’s da União Europeia com as ex-colônias para ter acesso ao mercado europeu em melhores condições do que se exportando produtos direto do Brasil é uma possibilidade que atrai muitos investidores brasileiros.

\footnotetext{
${ }^{33}$ A preferência por cada estratégia de entrada nos mercados varia de setor para setor, de forma que as empresas do setor de recursos naturais, como a Vale, por exemplo, acabam preferindo o estabelecimento de alianças e parcerias devido à experiência agregada do parceiro local.

${ }^{34} \mathrm{O}$ modelo tradicional de uma estrutura fragmentada seria aquele com a intervenção do "Ministério dos Negócios Estrangeiros”, por um lado, responsável pela gestão da componente política e de cooperação, e do Ministério da Economia, por outro, com preponderância na vertente negócios.

${ }^{35}$ A América do Norte chegou a ter uma queda de $47 \%$ no índice de regionalidade em função da crise internacional.
} 
No governo Lula, a instalação de empresas brasileiras teve um papel importante nas relações com a África, na medida em que foram vistas como instrumentos para fortalecer os laços com os países do continente, sendo favorecidas pela política diplomática presidencial. Esse apoio foi instrumentalizado principalmente pelo aumento de missões empresariais, tanto acompanhando o Presidente e o Ministro das Relações Exteriores, quanto em missões de outros ministérios, como a "Missão do MDIC à África Ocidental”, que visitou Senegal, Nigéria, Gana e Guiné Equatorial, buscando promover o aumento do comércio e dos investimentos naquela região. Outra iniciativa nesse sentido foi o Acordo para evitar Dupla Tributação com a África do Sul (2003), medida está que é considerada pela rede de firmas KMPG uma vantagem a ser observada para o sucesso da estratégia de internacionalização das empresas.

A vertente da cooperação tem atuado também no sentido de contribuir para a atuação das empresas brasileiras na África, ao implementar programas de treinamento e formação de mão-de-obra local que possa trabalhar nos empreendimentos brasileiros. O Serviço Nacional de Aprendizagem Industrial SENAI já colocou em funcionamento centros de formação profissional em Angola, Cabo Verde, Guiné-Bissau, sendo que o de Angola, em 2005, já teve sua gestão transferida para o governo angolano. Estão previstos também a criação de centros de treinamento em São Tomé e Príncipe e Moçambique.

Uma recente iniciativa no âmbito da Agência Brasileira de Promoção de Exportações e Investimentos (APEX-Brasil) foi a criação do Centro de Negócios em Luanda, Angola, em Novembro de 2010, o qual trabalhará no apoio à instalação local de empresas brasileiras e estudos e planos de negócios para entrada no mercado, além de outros mecanismos de apoio à exportação. Alguns eventos também se destacam, como o Brasil Agri-Solutions e a Feira Internacional de Angola (FILDA). Para se ter uma ideia da importância dessas iniciativas, na FILDA de 2010 participaram 40 empresas brasileiras e o estande do Brasil, o segundo maior da feira, recebeu cerca de 20 mil visitantes, o que rendeu US\$ 50 milhões em negócios, valor 66\% superior ao de 2009. (APEX, 2010)

O que esses investimentos diplomáticos e governamentais, na verdade, fazem, além de fomentar a instalação dessas empresas, é promover a marca Brasil. Segundo 
Amaral (2008), um dos desafios da empresa que se internacionaliza é a consolidação de sua marca em um mercado desconhecido; a promoção desta é responsabilidade da empresa, mas a marca País, no caso a marca Brasil, a qual anda junto com a marca da empresa, é responsabilidade do governo. O autor explica que a marca País é como um passaporte que acompanha o produto e que pode contribuir para gerar simpatias ou desconfianças.

Nesse sentido, uma pesquisa do Instituto de Estudos Estratégicos Internacionais - IEEI (2010) aponta a percepção dos angolanos e moçambicanos a respeito da presença de atores estrangeiros em seus respectivos países. Em relação a Angola, o Brasil figura entre os três primeiros países quanto a sua importância e influência e na mesma posição na percepção dos atores locais com quem é prioritário reforçar as relações no futuro. Já em relação a Moçambique, o Brasil está em $11^{\circ}$ para a influência atual e em $5^{\circ}$ nas prioridades para o futuro.

A promoção dos investimentos brasileiros na África, porém, não fica a cargo apenas das iniciativas governamentais. Os empresários brasileiros que atuam em Angola organizaram-se, desde 2003, em torno da Associação de Empresários e Executivos Brasileiros em Angola - AEBRAN, com o objetivo de agregar e representar os empresários e executivos brasileiros estabelecidos nesse país. Apesar de uma iniciativa privada, a AEBRAN atua na Comissão de Brasileiros no Mundo, representando o continente africano junto ao Itamaraty.

Mapeando os investimentos brasileiros na África, essa pesquisa identificou 22 países nos quais existem ou existiam empresas brasileiras, sendo os setores de minerais e construção civil os mais consolidados e o das pequenas e médias empresas e franquias os com maior potencial para o futuro. O setor de serviços também se destaca, mas este é mais presente onde os investimentos brasileiros em outras áreas são mais significativos. Dentre as empresas identificadas, a Odebrecht apresenta os vínculos mais sólidos com o continente, tanto em interação com a economia e sociedade locais, quanto na multiplicação de benefícios para o desenvolvimento dos países onde atua. Os países onde há maior volume de investimentos serão analisados individualmente a seguir. Os demais países apresentam em média uma ou duas empresas apenas. 


\section{1. África do Sul ${ }^{36}$ :}

A África do Sul, mais do que a maior economia da África, com melhor infraestrutura, economia mais sofisticada e ambiente de negócios mais estável e confiável, é o portão de acesso (gateway) ao mercado dos demais países africanos. O país é um tradicional parceiro do Brasil em termos comerciais e agora começa a destacar-se como destino dos investimentos externos diretos brasileiros.

O perfil das empresas brasileiras que atuam na África do Sul é de grandes corporações do setor privado, mediante a abertura de escritórios regionais, fábricas e prestando serviços. Porém, os setores que se destacam em termos de potencial para o futuro são aqueles de controle estatal, como indústria bélica e tecnologia de TV digital.

A Vale atua na África do Sul na exploração de minérios, onde a empresa instalou seu principal escritório do continente. A importância do país para esta empresa está em ele ser considerado o maior produtor mundial de platina, cromo e ouro (VIZENTINI, 2010). Já a empresa de ônibus Marcopolo atua no país desde 2000 e tem uma fábrica própria instalada lá. Recentemente a empresa passou por uma reestruturação administrativa, criando subdivisões regionais, com o intuito de aumentar a produtividade e a eficiência, apostando no crescimento do mercado africano.

A Marfrig, dona da marca Seara, também tem fábrica própria instalada na África do Sul, com capacidade de produção de 21.000 unidades de couro por dia (MARFRIG, 2011). A Odebrecht, apesar de ser uma empresa bastante atuante no continente africano, atualmente não atua na África do Sul, tendo realizado sua última obra em 1998. Além disso, no setor privado se destacam as franquias de marcas brasileiras, as quais serão analisadas em um item específico para elas.

Quanto ao potencial para o futuro, Vizentini relembra que o regime militar no Brasil e o do Apartheid na África do Sul desenvolveram eficientes indústrias armamentistas, aeronáuticas e tecnologia nuclear, que no período subsequente em ambos os países entraram em declínio, mas que agora existe campo para retomar os

\footnotetext{
${ }^{36}$ Mercado sul-africano ficou isolado durante alguns anos em função das sanções contra o regime do Apartheid, mas voltou à normalidade a partir de 1994, com a eleição de Mandela.
} 
projetos. Apesar de os temas de defesa serem limitados à esfera da soberania, a coordenação nessa área é possível. Outro mercado potencial é, caso a África do Sul acorde a adoção do padrão nipo-brasileiro de TV digital, que as micro, pequenas e médias empresas sul-africanas associem-se a empresas brasileiras no mercado de TV digital.

\subsection{Angola:}

Angola é o principal receptor de investimentos brasileiros no continente africano (LIMA, apud MICOLO, 2010). Apesar de manter índices de crescimento elevados há alguns anos, Angola é valorizada por ter ainda grande capacidade ociosa para investimentos, além de recursos naturais, como hidrocarbonetos, pedras preciosas, outros minerais, recursos hídricos, terras cultiváveis, entre outros. Ademais, o país está implementando programa de substituição de importações, contexto em que a instalação das empresas brasileiras é uma inciativa apropriada (SALOMÃO, 2008:37).

A atuação de empresas brasileiras em Angola é fruto de uma relação histórica, iniciada a partir da vanguarda brasileira no reconhecimento da independência do país, em 1975, sob o governo do MPLA, liderado por Agostinho Neto. A Petrobrás chegou no país a convite do líder do MPLA logo após a independência, seguida pela Construtora Norberto Odebrecht. Os anos que seguiram, porém, foram de violenta guerra civil, destruição da infraestrutura e desarticulação da economia, de forma que os investimentos, em especial da Petrobras, foram de baixa intensidade ${ }^{37}$.

O fim da guerra civil, em 2002, após a morte do líder da Unita, Jonas Savimbi, liberou o país dos constrangimentos que recaíam sobre o investimento estrangeiro em Angola. Cabe, porém, ressaltar que, apesar de Robert Gilpin (2002;277) afirmar que as empresas prezam mais a estabilidade política do que a forma específica de governo, as empresas brasileiras permaneceram em Angola mesmo durante os quase trinta anos de guerra civil. Não obstante esse fato, percebese a abertura de um leque de oportunidades com a pacificação do país.

\footnotetext{
${ }^{37}$ Luiz Alfredo Salomão, porém não vê nesse fato um empecilho aos investimentos e afirma que a Petrobras perdeu oportunidades que foram aproveitadas por outras petroleiras.
} 
Salomão (2008) relembra que, no momento atual, a concorrência para investir no país é grande e “os interesses econômicos se sobrepõem aos afetos históricos pelos brasileiros” (SALOMÃO, 2008:36-37), de forma que recomenda algumas medidas para que a presença do Brasil seja mais competitiva, como a criação de um ambiente de negócios especial entre os dois países, com a dispensa de vistos tanto para visitas de negócios como para trabalhadores ${ }^{38}$, além de sugerir que as empresas brasileiras sejam equiparadas às angolanas para simplificar o trâmite burocrático de seu registro. Além da concorrência e da burocracia, as empresas que querem se instalar em Angola encontram um outro obstáculo, enquadrado no custo Angola, que é o fato de o país ter sido considerado pela ONG Transparência Internacional o segundo país mais corrupto do mundo ${ }^{39}$ (SALOMÃO, 2008: 43).

Ainda assim, diversas empresas investem em Angola. A construtora Norberto Odebrecht iniciou seus trabalhos no país em 1984, com a construção da hidrelétrica de Capanda, na qual foi responsável pelas obras civis, além de treinar 3 mil angolanos ligados ao projeto. Essa obra é a mais difundida na bibliografia sobre os investimentos brasileiros no país, até por ter sido a pioneira da empresa, mas, ao longo desses 27 anos de atuação, a Odebrecht já concluiu 16 projetos no país, que variam desde a construção de condomínios de casas e shopping centers até obras de saneamento básico, canais de irrigação para agricultura, obra em termoelétrica e associação para a produção de diamantes (ODEBRECHT, 2011). A empresa dá destaque às obras de reabilitação dos $42,6 \mathrm{~km}$ do canal irrigação de Matala, ao projeto de saneamento Águas de Luanda e o Condomínio Atlântico Sul. Além disso, no momento existem 47 projetos em andamento, que inclui barragens, autoestradas, desenvolvimento diamantífero, linha de transmissão Capanda-Lucala-Viana e o Polo Industrial de Viana (ODEBRECHT, 2011).

Um fato que se destaca na atuação da Odebrecht em Angola são os investimentos em responsabilidade social. Em todo o período de atuação no país, a empresa formou 10 mil profissionais locais, transferiu tecnologia e foi substituindo

\footnotetext{
${ }^{38}$ O mesmo autor ressalta a situação "inconcebível” de brasileiros sem visto de trabalho que trabalham na clandestinidade e são obrigados a voltar ao Brasil a cada dois meses para renovar os vistos de turista.

${ }^{39}$ Salomão relembra a tradição que se criou nos meios empresariais estrangeiros de que para investir em Angola era necessário encontrar um “general disposto a participar do negócio” e acrescenta que as empresas brasileiras têm encontrado "o general certo".
} 
gradativamente a mão-de-obra brasileira pela angolana. Projetos na área de prevenção à Aids, Programa de Saúde da Mulher, campanhas de vacinação contra a poliomielite, conscientização ambiental e incentivo a retorno de angolanos residentes no Rio de Janeiro em condições precárias são algumas das ações sociais da empresa (ODEBRECT, 2011). Esse tipo de ação, convém destacar, é que produz a percepção positiva por parte dos angolanos em relação à presença brasileira no país, como foi visto no estudo do IEEI mencionado acima.

A Petrobrás, pioneira brasileira em investimentos em Angola, até 2006 teve uma atuação limitada, participando apenas na condição de sócia, sem a operação em trabalhos de prospecção, de forma que sua produção se limitava a 2,8 mil barris por dia. Entre 1979 e 2006, a Petrobrás foi sócia não-operadora em apenas dois blocos, o 2/85 e o 34. Porém, a partir de 2006, a Petrobrás passou a investir de forma mais agressiva no país, ao conquistar direitos de exploração e produção em mais quatro blocos, sendo operadora em três deles. A expectativa é de elevar significativamente a produção, dos 2,8 mil para 100 mil barris/dia, com o compromisso de perfuração de onze poços até este ano de 2011.

Já a Vale possui escritório em Luanda Sul e atua em pesquisas para a identificação de áreas com potencial para cobre e níquel. Assim como será visto no item dedicado a Moçambique, as empresas de TV brasileiras, Globo e Record, aproveitam-se da semelhança da língua e do crescimento econômico do país para competirem por fatias do mercado angolano. Furnas, Camargo Corrêa, Totvs (Microsiga), Stefanini IT Solutions, Costa Negócios e Tecnologia são outras empresas identificadas por essa pesquisa atuando em Angola. Além disso, a Enashop, empresa que administra o shopping Barra, em Salvador, na Bahia, também está administrando o Belas shopping, em Luanda, o qual foi construído pela Odebrecht junto com uma empresa local.

As marcas brasileiras, entrando no mercado angolano por meio de franquias, têm ganhado grande destaque na estratégia brasileira em direção ao país. Angola é o país na África que mais recebe essas empresas. Esse tema, porém, será visto em separado por não se tratar de investimentos brasileiros propriamente ditos, mas sim marcas brasileiras, cuja propriedade da empresa que a usa pode ser de um nacional de país africano ou de investidores extracontinentais. 


\subsection{Líbia:}

Antes de tratar especificamente dos investimentos brasileiros na Líbia, pelo fato de esta monografia estar sendo escrita em meio a levantes no mundo árabe, em que a Líbia está convulsionada, sob sanções do Conselho de Segurança da ONU e ataque aéreo dos EUA, França e Inglaterra, convém advertir que o quadro relatado provavelmente sofrerá alterações significativas à medida que o conflito se desenrole.

O regime de Muammar Quaddafi, logo que foi instituído no final dos anos 1960, tentou implantar uma espécie de “socialismo Beduíno” (THE ECONOMIST, 2011), confiscando bens e dando poder a comitês populares. Mais recentemente, porém, com a normalização das relações do país com a comunidade internacional, o regime de Quaddafi procurou promover uma maior abertura do país à economia mundial e passou a convidar empresas estrangeiras a investirem no país e a incentivar a iniciativa privada ${ }^{40}$.

A abertura da Líbia ao capital internacional estava inserida em um plano de desenvolvimento, no qual o país procurava se qualificar para ser a principal porta de entrada da África. Desde 2003, quando as sanções do Conselho de Segurança das Nações Unidas (C.S.), que vigoravam desde 1992, foram suspensas, Trípoli vinha experimentando uma forte aceleração do crescimento. Nesse contexto, em 2005, chega ao país a estatal brasileira de petróleo, a Petrobrás, após vencer a primeira rodada de licitações da estatal líbia, Nacional Oil Corporation (NOC). No país, a Petrobrás adquiriu direitos exploratórios de petróleo e gás e de partilha da produção da área 18, da qual é a operadora do consórcio que opera na exploração do bloco, com 70\% de participação (PETROBRAS, 2011)

Já a construtora Norberto Odebrecht chegou ao país em 2006 para a construção do Anel Rodoviário de Trípoli, uma obra estimada em 250 milhões de euros (ODEBRECHT, 2011) e de grande necessidade para viabilizar o crescimento que a cidade vinha demonstrando. Na Líbia, a Odebrecht atua por meio da LibyanBrazilian Construction \& Development (LBCD), que é uma empresa líbia, constituída em sociedade com a Urban Development Holding Company (UDHC),

\footnotetext{
${ }^{40}$ A mão-de-obra do país contava antes do início dos conflitos com nada menos do que 1,5 milhões de trabalhadores estrangeiros (THE ECONOMIST, 2011).
} 
sendo a Odebrecht a controladora, com $60 \%$ de participação acionária. O contrato do Anel Rodoviário foi o primeiro da LBCD.

Outro projeto da Odebrecht na Líbia é a construção de dois terminais do Aeroporto Internacional de Trípoli, de envergadura bem maior que o primeiro projeto, orçado no valor de 970 milhões de euros (ODEBRECHT, 2011). Esse projeto é estratégico, na medida em que a posição geográfica do país, segundo o presidente da Libyan Civil Aviation Authority, oferece a melhor ligação entre a Europa e os países da União Africana. Além da estrita regulamentação ambiental, outro desafio da obra é o multicultural: serão trabalhadores de até 30 nacionalidades ${ }^{41}$ diferentes trabalhando na parte mais intensa da obra, sendo mais de 300 no escritório e até 6 mil no campo de obras (ODEBRECHT, 2011). Além disso, a obra era executada por uma joint venture entre a Odebrecht, uma empresa turca e uma empresa grega, com a liderança da Odebrecht, com 50\% de participação (ODEBRECHT, 2011).

Como é prática da empresa, a Odebrecht realiza projetos sociais no país com a comunidade da área próxima às obras e com o treinamento de mão de obra local. Isso demonstra um investimento para a sustentabilidade daquilo que a própria empresa planejava antes da guerra, continuar investindo no país, de forma a tornar a LBCD a maior empresa de construção na Líbia. Além da Odebrecht, as construtoras Andrade Gutierrez e Queiroz Galvão também atuavam no país. Vale ressaltar que, ao contrário do que ocorreu em Angola, na Líbia, as empresas brasileiras não permaneceram durante o conflito, colaborando, inclusive com o Ministério das Relações Exteriores do Brasil (MRE) na retirada dos brasileiros que estavam no país.

\subsection{Moçambique:}

Moçambique, até bem pouco tempo atrás era um destino incipiente dos investimentos brasileiros. O marco foi $2007^{42}$, quando a Vale conquistou os direitos de exploração das reservas de carvão de Moatize. O projeto, que foi lançado em

\footnotetext{
${ }^{41}$ Só nos primeiros meses de trabalho, já havia profissionais do Brasil, Líbia, Turquia, Egito, Jordânia, Portugal, Inglaterra, Colômbia, Peru, Síria Estados Unidos e Gana (ODEBRECHT, 2011).

${ }^{42} \mathrm{Em}$ 2007, o Brasil figurava entre os 9 maiores investidores em Moçambique (AGÊNCIA LUSA \&AGÊNCIA DE NOTÍCIAS DA AIDS, 2008).
} 
2009, vai produzir 11 toneladas de carvão por ano, o qual vai ser exportado para Brasil, Europa, Ásia e Oriente Médio (VIZENTINI, 2010). Estima-se que com esse empreendimento, Moçambique se torne o segundo maior produtor de carvão do continente, atrás apenas da África do Sul.

Esse projeto é o de maior relevo realizado por uma empresa brasileira no país, alavancando a participação de outras 20 companhias nacionais. Convém, porém, antes de elencar os demais investimentos, caracterizá-los. As empresas brasileiras que atuam em Moçambique são em sua maioria multinacionais do setor privado, atuando principalmente na área de infraestrutura e grandes obras, por meio tanto da presença direta das empresas, quanto por aquisições e participação em empresas que já atuam no país. Esse perfil traçado, contudo, trata-se de uma generalização, havendo espaço também para outras empresas de capital público, de menor porte e em outras áreas que não infraestrutura.

Além da Vale, outra empresa que se destaca na atuação em Moçambique é a construtora Norberto Odebrecht. Essa empresa, na década de 1990, atuou na construção da rodovia EM-6 ligando Inhope a Machipanda, porém, por questões estratégicas da empresa, se retirou do país, só retornando em 2005 para construir as instalações da gigantesca mina de Moatize que a Vale vai explorar. Em função da envergadura do empreendimento, a Odebrecht formou com a Camargo Corrêa o Consórcio Moatize, o qual assinou com a Vale um contrato de aliança, para ter a estrutura necessária em termos de mão de obra e logística ${ }^{43}$ para a realização do empreendimento. Além das obras da mina, infraestrutura de rodovias e a construção da usina de beneficiamento de carvão mineral, a Odebrecht também ficou responsável pela construção da vila que receberá as famílias desapropriadas pela construção da mina (ODEBRECHT, 2011). O projeto Moatize está em andamento no momento.

Ademais do consórcio com a Odebrecht, a Camargo Corrêa adquiriu 51\% da empresa Cimento de Nacala, do grupo moçambicano Insitec, parte da cimenteira portuguesa Cimpor (O PAÍS, 2010) e, em 2007, apresentou o projeto para a construção da hidrelétrica Mphanda Nkuma, no centro do país (SBI, 2008). Na área de serviços, há aproximadamente 10 anos as emissoras de TV Globo e Record têm

\footnotetext{
${ }^{43}$ Moatize fica a mais de $1.500 \mathrm{~km}$ de Maputo, a capital.
} 
disputado o mercado moçambicano, que é beneficiado por ter língua comum com o Brasil, pela simpatia que esse país dedica à cultura brasileira ${ }^{44}$ e por estar passando por um momento de crescimento acelerado.

$\mathrm{Na}$ área dos investimentos estatais, a Eletrobrás, controlada pelo governo brasileiro, é uma das grandes empresas que atuam em Moçambique. Em 2010, foi celebrado um acordo entre o governo dos dois países para que a Eletrobrás realize o estudo para a construção de uma linha de transmissão de alta tensão de $1.400 \mathrm{~km}$, ligando a província de Tete a Maputo, a linha Centro-Sul, também chamada de “espinha dorsal” (O PAÍS, 2010). Além da Eletrobrás, a Petrobras, em 2007, assinou acordos com a Empresa Nacional de Hidrocarbonetos - ENH, a companhia nacional de Moçambique, na área de pesquisa em biocombustíveis ${ }^{45}$.

Mas a despeito de existirem investimentos de vulto promovidos por grandes multinacionais, um dos setores que mais tem se destacado recentemente é o das pequenas e médias empresas. Nesse sentido, em 2005, o empresário moçambicano Ermelindo Marques fundou a Central de Negócios Brasil Moçambique, apostando na potencialidade desse tipo de investimento (MOÇAMBIQUE PARA TODOS, 2011). Apesar de muito falado na mídia desse país africano, o tema está ainda na seara das potencialidades.

\subsection{Franquias de marcas brasileiras:}

A presença de franquias de marcas brasileiras na África tem sido uma vertente de destaque nos últimos tempos. Como já foi afirmado, a análise em separado desse tema se deve ao fato de a internacionalização de franquias brasileiras não necessariamente implica na presença de empresas brasileiras, mas sim de marcas, uma vez que a franquia pode ser de propriedade de um nacional do país onde ela está se instalando ou de um estrangeiros que queira investir nesse país. Nesse sentido, um dos principais motivos alegados pelas franquias para internacionalizar-se

\footnotetext{
${ }^{44}$ Nesse sentido, a emissora Record atua duplamente, na medida em que a TV é de propriedade de Edir

Macedo, fundador da Igreja Universal do Reino de Deus, à qual Vizentini (2010) atribui fator de projeção da cultura brasileira na África.

${ }^{45}$ Note-se que a Petrobras não realiza nem exploração nem produção de petróleo em Moçambique. O acordo restringe-se à pesquisa na área de biocombustíveis.
} 
é o fortalecimento da imagem da empresa (MARQUES, 2007).

A pesquisa realizada por essa monografia identificou franquias de marcas brasileiras presentes em Angola, África do Sul, Nigéria e Egito. Os principais setores identificados foram serviços, vestuário, calçados, alimentos e cosméticos e beleza em geral. Dentre esses países o que mais se destaca é Angola. O país aparece como o destino inicial de 9,1\% das empresas pesquisadas por Danton Siqueira Pitta Marques (2007), atrás apenas de Portugal, México e Argentina (MARQUES, 2007). Já como destino principal $^{46}$ da franquia, a posição de Angola sobe, ficando em terceiro lugar, representando 9,1\% das empresas (MARQUES, 2007). Das marcas identificadas por essa pesquisa, Angola recebeu 15 franquias brasileiras ${ }^{47}$, enquanto a África do Sul, o segundo colocado, recebeu 4, Egito 2 e Nigéria apenas 1.

Algumas marcas que podem ser citadas são O Boticário, que atua em Angola e na África do Sul; o curso de línguas Fisk, considerada uma franquia com selo de excelência pela Associação Brasileira de Franchising, atua em Angola tanto em empresas, treinando funcionários, quanto em curso aberto ao público; a marca Via Uno, presente na África do Sul e no Egito; e a Hoken, na Nigéria, que trabalha com produtos para tratamento de água.

Investimentos governamentais e as oportunidades dessa fatia de mercado apresentam perspectivas positivas para o futuro das franquias brasileiras na África. Em 2010, o projeto Franchising Brasil, desenvolvido pela APEX-Brasil e a Associação Brasileira de Franquias, participou pela primeira vez da FILDA, expondo 5 marcas brasileiras de Franquias, sendo que logo no primeiro dia a Wizard fechou contrato de representação exclusiva para a abertura de uma rede de escolas de idioma em Angola (APEX-BRASIL, 2010). Assim, trata-se de um grande potencial para fortalecer a presença brasileira no continente africano.

\footnotetext{
${ }^{46} \mathrm{O}$ destino inicial corresponde ao primeiro país para o qual uma empresa decide internacionalizar sua franquia e o destino principal é o que tem maior número de franquiadas.

47 A APEX identifica franquias de 17 marcas brasileiras em Angola, mas o critério utilizado pela agência inclui franquias como a do BOB’s, que é originária dos Estados Unidos, mas que a partir do Brasil está abrindo franquias em Angola. A pesquisa realizada nessa monografia inclui apenas marcas efetivamente brasileiras.
} 


\section{CONCLUSÃO}

Essa monografia pretendeu fazer um mapeamento dos investimentos brasileiros na África durante o governo Luís Inácio Lula da Silva. Pode-se observar que no período em tela houve um incremento dos investimentos brasileiros no continente, assim como da internacionalização da economia do país como um todo. Observou-se, contudo, que mais do que um grande projeto, esse aumento foi em grande medida favorecido pela convergência de crescimento da economia mundial, crescimento interno com estabilidade da economia brasileira e o Renascimento Africano, que produziu índices de crescimento do PIB significativos.

Não obstante essa convergência de momentos favoráveis, houve relevante investimento diplomático do governo Lula, de forma a se destacar em ralação à política externa para a África de outros governos. Do lado da África, a receptividade a esses investimentos também foi verificada, inclusive com iniciativas no âmbito da NEPAD para fomentar esses investimentos e tornar os países africanos mais atrativos do ponto de vista institucional ${ }^{48}$.

Tanto em relação à África como ao Brasil, a aproximação se insere em estratégias de inserção internacional e de desenvolvimento econômico mais amplas. A NEPAD visa uma atuação mais autônoma da África, reduzindo a dependência em relação às potência tradicionais, e dinamizando a economia do continente, casos em que a presença do Brasil se adequa à expectativa. Como país emergente que busca expandir seus investimentos internacionais, o Brasil se apresenta como parte de uma nova classe de atores interessados em investir na África, os emergentes, e como seu interesse é em investimentos diretos e os setores que se destacam são aqueles da infraestrutura e exploração de minerais, o Brasil também atende ao perfil de desenvolvimento econômico pretendido pela NEPAD.

Já a África para o Brasil faz parte da estratégia de relações Sul-Sul, em que o Brasil busca relações horizontais com países em desenvolvimento, em oposição à verticais com os países desenvolvidos. Esse perfil de relações dá maior margem de manobra para o Brasil dar vasão ao crescimento econômico do país e à maior internacionalização da economia. Mas, não apenas econômico, o interesse do Brasil

\footnotetext{
${ }^{48}$ Afinal, em termos de recursos eles já são bastante atraentes.
} 
na África também é político, buscando nos países do continente o apoio e os votos necessários às reformas da governança global que o governo Lula elegeu como prioritárias.

No primeiro capítulo, foi analisada a nova inserção internacional da África, em especial nos anos 2000, após passar por uma fase de instrumento para as disputas da Guerra Fria, no período que seguiu às independências, e outra de ostracismo pela perda de valor estratégico, na década de 1990. No início do século XXI, a inserção internacional da África apresenta melhoras qualitativas impulsionadas por dois fatores inter-relacionados: o lançamento da NEPAD e a "nova partilha da África”, sendo o primeiro uma iniciativa autonomista e autóctone visando uma nova forma de inserção internacional e a segunda a procura de países desenvolvidos, mas, principalmente, dos em desenvolvimento, de novas áreas para investimento e para suprir suas necessidades de recursos naturais e que encontram em uma África mais estável e com altos índices de crescimento, além de fartos recursos naturais, uma ótima oportunidade.

No segundo capítulo, analisou-se a política externa para a África do Governo Lula, a qual retoma em grande medida linhas de ação de projetos anteriores de política externa em que a África era contemplada de forma mais ativa, mas avança, repudiando as relações meramente instrumentais, como ocorria no passado e trazendo uma série de elementos de coesão e coordenação interna que sustentam a política. Além de inovar em relação aos projetos anteriores, a política de Lula para a África dá um salto em relação à política externa do governo Fernando Henrique, o qual fechou postos no continente, reduziu os contatos e os investimentos diplomáticos, o que repercutiu nos fluxos de comércio e investimentos e gerou um afastamento geral entre o Brasil e a África. Essa nova política para a África do governo Lula insere-se em um projeto mais amplo de política externa em que o Brasil voltou-se para as relações Sul-Sul como prioridade da sua ação exterior e assumiu um papel mais protagônico.

Enquanto nos dois primeiros capítulos foi apresentado o contexto em que os novos investimentos brasileiros chegam à África e, de certa forma, o motivo pelo qual eles tiveram um incremento na última década, no terceiro capítulo as empresas brasileiras na África foram efetivamente mapeadas. Como foi visto, os países que se 
destacam como destino das empresas brasileiras são África do Sul, Angola, Líbia e Moçambique. No entanto, existem ou existiram empresas brasileiras nos últimos anos em 22 países africanos e esses investimentos são principalmente na área de minerais e construção civil, sem contar com o potencial das pequenas e médias empresas e das franquias.

Assim, o mapa dos investimentos brasileiros na África poderia ser sintetizado em uma intensa concentração de pontos na África Austral, com a exceção da Líbia no norte do continente, que se difere não apenas geograficamente, mas culturalmente também, por ser um país árabe face aos demais da África negra, e pontos esparsos por todo o resto do continente. 


\section{BIBLIOGRAFIA}

ABERT. Empresários Brasileiros e Sul-Africanos Discutem TV Digital. Disponível em: http://www.abert.org.br/site/index.php?/Clipping-2010/2oedicao-empresarios-brasileiros-e-sul-africanos-discutem-tv-digital.html Acesso em: 13/03/2011.

ABF; ESPM. Processos e Barreiras para a Internacionalização de Empresas Brasileiras. Disponível em: http://mundodofranchising.blogspot.com/2011/01/franquias-brasileiras.html Acesso em: 13/03/2011.

AEBRAN. AEBRAN. Disponível em: http://www.aebran.com/quemsomos.php Acesso em: 16/08/2010.

AGÊNCIA LUSA; AGÊNCIA DE NOTÍCIAS DA AIDS. Lula vai Discutir Fábrica de Antirretrovirais em Moçambique. Disponível em: $<$ http://www.infectologia.org.br/default.asp?site_Acao=mostraPagina\&paginaId= $\underline{134 \& m N o t i \_A c a o=m o s t r a N o t i c i a \& n o t i c i a I d=2479}>$ Acesso em: 06/03/2010 AMARAL, Sérgio. Internacionalização das Empresas Brasileiras. Política Externa nº 4, vol. 16, Março, Abril, Maio 2008.

AMORIM, Celso. Lecture given by Foreign Minister Celso Amorim at a Seminar organized by the Valor Econômico and Wall Street Journal newspapers, New York, 16 $^{\text {th }}$ March 2009. In Brazilian Foreign Policy Handbook 2008-2009. Brasília: FUNAG, 2010.

ANGOP. Belas shopping inaugurado em Luanda. Disponível em: http://www.angonoticias.com/full_headlines.php?id=13937 Acesso em: $20 / 03 / 2011$

APEX-BRASIL. África e Oriente Médio. Disponível em: http://www.apexbrasil.com.br/portal/ Acesso em: 27/02/2011

APEX-BRASIL. Empresas brasileiras encerram FILDA 2010 com negócios estimados em 50 milhões de dólares. Disponível em: http://www.apexbrasil.com.br/Acesso em: 12/08/2010. 
APEX-BRASIL. Empresas brasileiras encerram FILDA 2010 com negócios estimados em 50 milhões de dólares. Disponível em: http://www.apexbrasil.com.br/ Acesso em: 12/08/2010

ASSOCIAÇÃO BRASILEIRA DE FRANQUIAS. Franquias com selo de excelência.

Disponível

em:

http://www.portaldofranchising.com.br/site/content/guiadefranquias/index.asp?co $\underline{\mathrm{dSeg}=\mathrm{EF}}$ Acesso em: 27/03/2011.

BARBOSA, Rubens. Internacionalização da Indústria Nacional. O Estado de São Paulo, 28/02/2006, Espaço Aberto, p. A2. Disponível em: http://www2.senado.gov.br/bdsf/bitstream/id/58517/1/noticia.html Acesso em: $09 / 07 / 2010$

BAUMANN. Renato. Brazilian External Sector do far in the 21th century. Revista Brasileira de Política Internacional special edition, 2010.

CARDOSO, Fernando Jorge (coord.). Diplomacia, Cooperação e Negócios: O Papel dos Atores Externos em Angola e Moçambique. Disponível em: http://www.ieei.pt/publicacoes/exemplar.php?exemplar=77 Acesso em: $16 / 08 / 2010$

CERVO, Amado Luiz. Inserção Internacional: formação dos conceitos brasileiros. São Paulo: Saraiva, 2008.

CERVO, Amado Luiz; BUEnO, Clodoaldo. História da Política Exterior do Brasil. Brasília: UNB, 2002.

CERVO, Amado Luiz; LESSA, Antônio Carlos. An Assessment of the Lula Era. Revista Brasileira de Política Internacional special edition, 2010.

CPLP. Como Surgiu. Disponível em: http://www.cplp.org/id-45.aspx Acesso em: 06/02/2010.

DÖPCKE, Wolfgang. O Encontro Estratégico: a União Africana, o Plano NEPAD e o novo discurso internacional. In: COELHO, Pedro Mota Filho e MENDONÇA, Hélio Magalhães de (org.). Relações Brasil-África: um colóquio. 
Brasília: Instituto de Pesquisa de Relações Internacionais - IPRI/FUNAG, 2002, p.143-182.

FOLHA.COM. Lula inicia visita à África sem chance de "levar Copa para casa”. Disponível em: http://www1.folha.uol.com.br/bbc/761225-lula-iniciavisita-a-africa-sem-chance-de-levar-copa-para-casa.shtml. Acesso em: $06 / 07 / 2010$

FRANÇA, Edson. O Renascimento do Continente Africano. Disponível em: http://www.abpn.org.br/index.php?option=com_content\&view=article\&id=306\% 3Ao-renascimento-do-continente-africano-e-tarefaantiimperialista\&catid=25\%3Aartigos\&Itemid=25\&lang=pt Acesso

em: 02/11/2010.

FUNDAÇÃO DOM CABRAL. Ranking Transnacionais Brasileiras 2010: repensando as estratégias globais. Disponível em: www.fdc.org.br Acesso em: 17/08/2010.

GILPIN, Robert. Economia Política das Relações Internacionais. Brasília: Editora Universidade de Brasília, 2002. 492p.

GUSSE, Celso. Os Desafios da SADC face ao Poderio Econômico da África do Sul. Disponível em: http://www.cemomozambique.org/index.php?option=com_docman\&task=cat_view\&gid=52\&limi

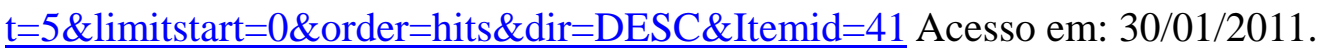
KPMG. Multinacionais Brasileiras: A Rota dos Investimentos Brasileiros no Exterior. Disponível em: http://www.kpmg.com.br/publicacoes_tax.asp Acesso em: 27/03/2011.

MARCOPOLO. Objetivo é aumentar a competividade e independência das operações. Disponível em: http://www.marcopolo.com.br/website/sa_pt/content/marcopolo/noticias/index.ph p?cdNoticia=1001 Acesso em: 13/03/2011

MARQUES, Dalton Siqueira Pitta. Internacionalização de Franquias: um mapeamento sobre a presença de redes brasileiras no exterior. Dissertação de Mestrado em Administração de Organizações, São Paulo: Universidade de São Paulo, 2007, 143p. 
MDIC. Balança Comercial Brasileira: dados consolidados 2009. Disponível em: http://www.mdic.gov.br//arquivos/dwnl_1275505327.pdf Acesso em: $02 / 04 / 2011$

MDIC. China se torna principal parceiro comercial do Brasil. Disponível em: http://www.mdic.gov.br/sitio/interna/noticia.php?area=5\&noticia=9041 Acesso em: 13/02/2011

MICOLO, Gaspar. Centro Brasileiros de Negócios em Angola é inaugurado em Dezembro. Jornal de Economia on line. Disponível em: http://www.jornaldeeconomia.com/index.php?t=Modulo\&action=view\&modulo $\underline{i d=1 \& i d=379 \& \text { table }=\text { noticia\&pg }=5}$ Acesso em: 20/03/2011

MOÇAMBIQUE PARA TODOS. Participação de Empresas Brasileiras Cresce em Moçambique. Disponível em: http://macua.blogs.com/moambique_para_todos/2007/09/participao-de-e.html Acesso em: 13/03/2011.

MONTE. João Bosco. China e África: a política de Pequim para o continente africano. Disponível em: http://mundorama.net/2010/03/03/china-e-africa-apolitica-de-pequim-para-o-continente-africano-por-joao-bosco-monte/ Acesso em: 17/11/2010.

MRE. Balanço da Política Externa 2003-2010. Disponível em: http://www.itamaraty.gov.br/temas/balanco-de-politica-externa-2003-2010 Acesso em: 07/02/2011.

NEW PARTNERSHIP FOR AFRICA DEVELOPMENT (NEPAD). Disponível em: http://www.nepad.org/images/framework.pdf Acesso em: 18/06/2010.

O PAIIS ON LINE. Empresas Brasileiras Ganham Terreno no País. Disponível em: http://www.opais.co.mz/index.php/desporto/38-economia/7112-empresasbrasileiras-ganham-terreno-no-pais.html Acesso em: 06/03/2011.

ODEBRECHT. Projetos Angola. Disponível em: http://www.odebrechtec.com.br/projetos/pais/angola Acesso em: 13/03/2011.

ODEBRECHT. Um país que se renova: obras do Aeroporto internacional e 
do Anel Rodoviário de Trípoli aprimoram a infra-estrutura da Líbia, que se qualifica para ser a principal porta de entrada da África. Acesso em: http://www.odebrechtonline.com.br/materias/01401-01500/1425/Disponível em: 20/03/2011.

OLIVEIRA, Amaury Porto de. A África no mapa econômico Mundial: o papel da China. Revista Política Externa. Vol. 16, n 3, dez-fev., 2008, p. 75-90.

PENNA FILHO, Pio. A África nas Relações Internacionais - Novas Possibilidades ou Nova Partilha? Disponível em: http://mundorama.net/2008/12/31/a-africa-nas-relacoes-internacionais\%e2\%80\%93-novas-possibilidades-ou-nova-partilha-por-pio-penna-filho/ Acesso em: $17 / 11 / 2010$.

PETROBRÁS. Angola. Disponível em: http://www.petrobras.com/ptcm/appmanager/ptcm/dptcm?_nfpb=true\&_pageLab el=petr_com_mundo_pais\&idConteudoPrincipal=pais_00017_Acesso em: $13 / 03 / 2011$.

PETROBRAS. Líbia. $\quad$ Disponível em: http://www.petrobras.com/ptcm/appmanager/ptcm/dptcm?_nfpb=true\&_pageLab el=petr_com_mundo_pais\&idConteudoPrincipal=pais_00019_Acesso em: $20 / 03 / 2011$

PIMENTEL, José Vicente de Sá. Relações entre o Brasil e a África SubSaariana. Revista Brasileira de Política internacional. Vol. 43, n 1, jan-jun 2000. Disponível em:

http://www.scielo.br/scielo.php?script=sci_arttext\&pid=S0034-

73292000000100001 Acesso em: 09/01/2011.

PORTAL DAS EMPRESAS - GOVERNO DE ANGOLA. Petrobras perfurará 11 poços exploratórios em Angola até 2011. Disponível em: http://www.angolanainternet.ao/portalempresas/index.php?option=com_content\& task=view\&id=468\&Itemid=71 Acesso em: 01/07/2010.

PRADO, Alfredo. TVs Brasileiras à Conquista das Audiências Africanas.

Revista $21 . \quad$ África Disponível 
em: 06/03/2010

SALOMÃO, Luiz Alfredo. Angola: desafios e oportunidades. Revista Política Externa. Vol. 17, n 1, jun-jul-ago 2008.

SARAIVA, José Flávio Sombra. A África na Ordem Internacional do Século XXI: mudanças epidérmicas ou ensaios de autonomia decisória? Revista Brasileira de Política Internacional. Vol. 1, n 51, 2008, p. 87-104. Disponível em: http://www.scielo.br/pdf/rbpi/v51n1/a05v51n1.pdf Acesso em: 02/11/2010 SARAIVA, José Flávio Sombra. A Nova Parceria para o Desenvolvimento Africano (NEPAD) no Contexto Internacional. In: COELHO, Pedro Mota Filho e MENDONÇA, Hélio Magalhães de (org.). Relações Brasil-África: um colóquio. Brasília: Instituto de Pesquisa de Relações Internacionais IPRI/FUNAG, 2002, p.125-142.

SARAIVA, José Flávio Sombra. Détente, diversidade, intranquilidade e ilusões igualitárias (1969-1979). In SARAIVA, José Flávio Sombra (Org). História das Relações Internacionais Contemporâneas: da sociedade internacional do século XIX à era da globalização. $2^{\mathrm{a}}$ Edição. São Paulo: Editora Saraiva, 2007.

SARAIVA, José Flávio Sombra. Olhares Transatlânticos: África e Brasil no Mundo Contemporâneo. Humanidades nº 47, Novembro 1999.

SARAIVA, José Flávio Sombra. The New Africa and Brazil in the Lula Era: the rebirth of Brazilian Atlantic Policy. Revista Brasileira de Política Internacional special edition, 2010.

SCHÜTZER, Hebert. África subsaariana: a última fronteira do capitalismo. Disponível em: http://mundorama.net/2009/07/07/africa-subsaariana-a-ultimafronteira-do-capitalismo-por-herbert-schutzer/ Acesso em: 17/11/2010. (artigo)

SILVA, Luiz Inácio Lula. Speech by Presidente Luiz Inácio Lula da Silva at the openning cerimony of the 13th African Unio Assembly, Sirte, 1st July 2009. In Brazilian Foreign Policy Handbook 2008-2009. Brasília: FUNAG, 2010. THE ECONOMIST. Endgame in Tripoli: the bloodiest of the north African 
rebellions so far leaves hundreds death. The Economist print edition, 24 de fevereiro 2011.

UNAIDS. East and Southern Africa. Disponível em: http://www.unaids.org/en/regionscountries/regions/easternandsouthernafrica/ Acesso em: 20/03/2011.

VALE. Vale no Mundo. Disponível em: http://www.vale.com/pt-br/conheca-avale/mundo-afora/Paginas/default.aspx Acesso em: 20/03/2011

VIGEVANI, Tullo e CEPALUNI, Gabriel. A política externa de Lula da Silva: a autonomia pela diversificação. Contexto Internacional, 29 (2), 2007.

VIZENTINI, Paulo Fagundes. A África na Política Internacional. Curitiba: Editora Jurua, 2010. 272p.

VIZENTINI, Paulo Fagundes. As Relações Internacionais da Ásia e da África. Petrópolis: Editora Vozes, 2007

WERNECK, Humberto. Tempo de Reencontros. Disponível em: http://www.odebrechtonline.com.br/materias/01901-02000/1914/ Acesso em: 13/03/2011. 